$$
\text { طرق دفع إيهام التعارض بين الأحادين العاديث العيني }
$$

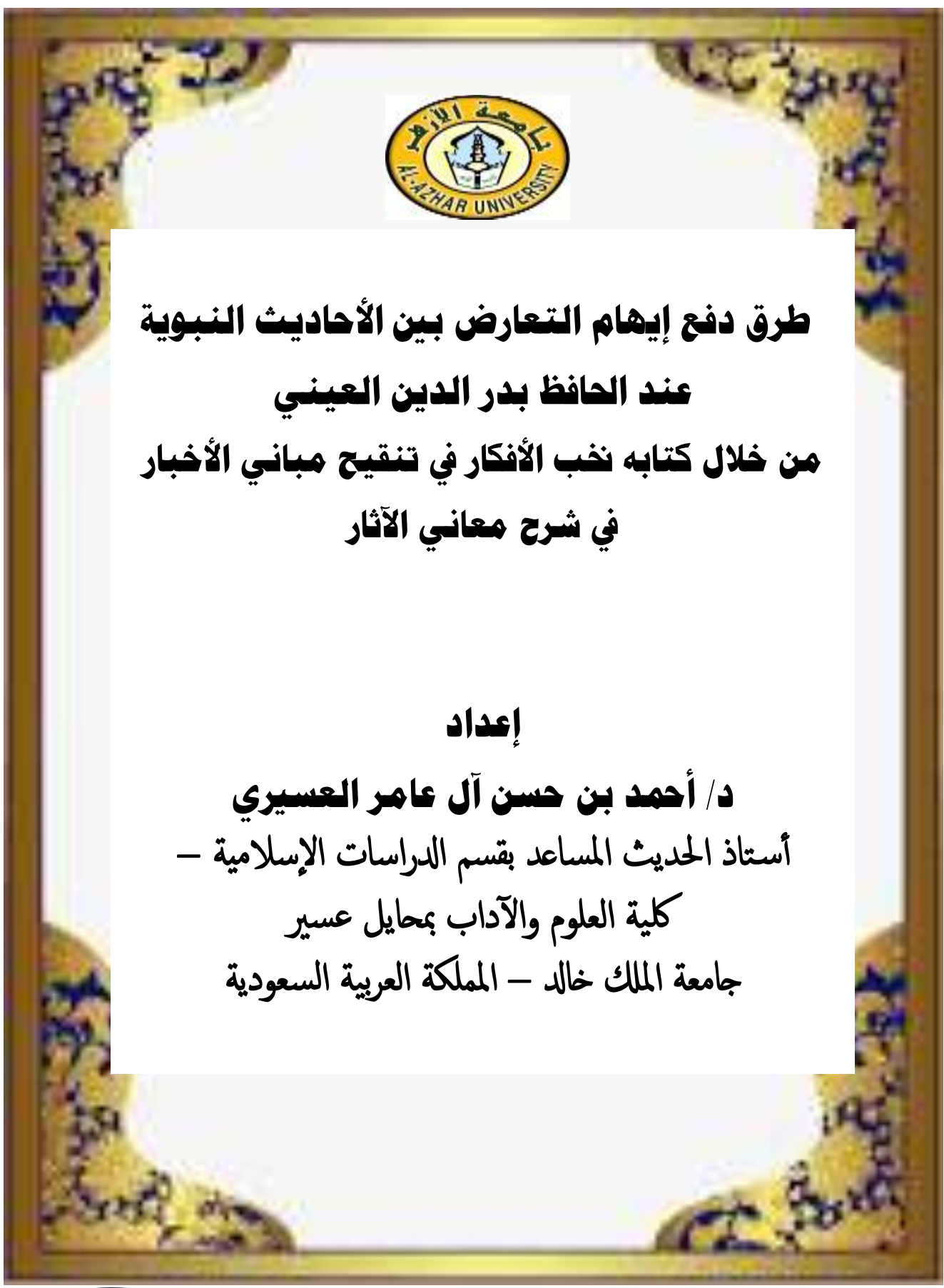

\title{
I. TV
}

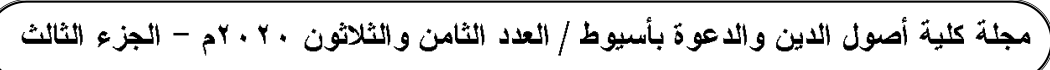




\section{طرق دفع إيهام التعارض بين الأحاديث النبوية}

\section{عند الحافظ بدر الدين العيني}

هن خلال كتابه نغب الأفكار في تنقيح هباني الأخبار

\section{في شرح معاني الآثار}

أحمد بن حسن آل عامر العسيري .

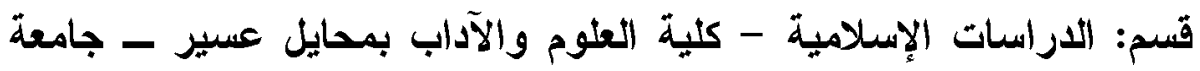
الملثك خالد - المملكة العربية السعودية ahalaseeri@kku.edu.sa البريد الالكتروني:

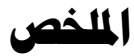

إنَّ موضوع التعارض والترجيح بين الأدلة الثرعية عمومًا، والروايات

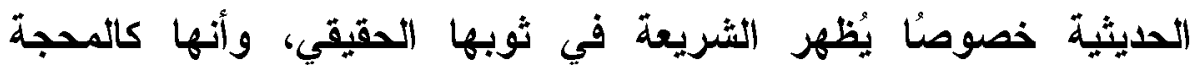

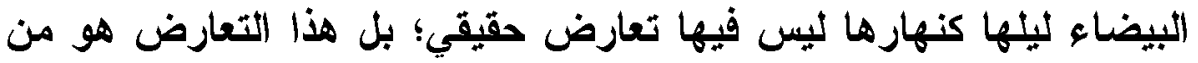

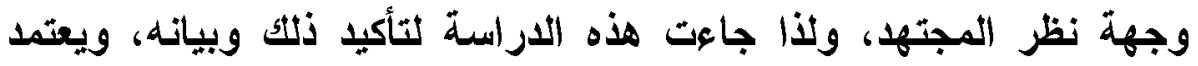

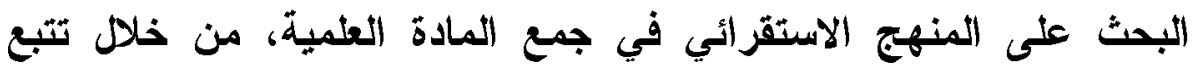

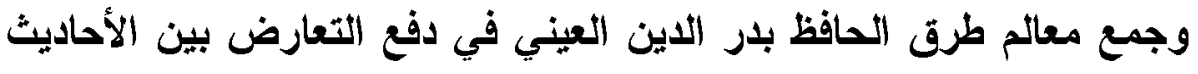

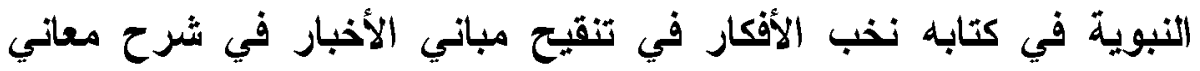

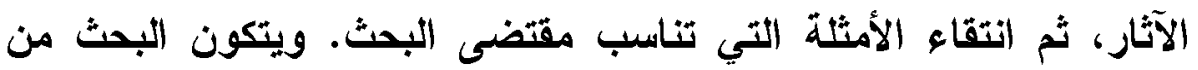

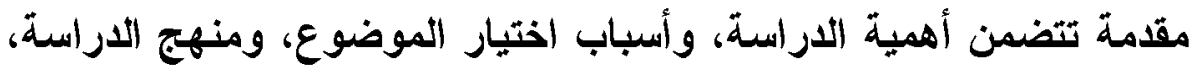

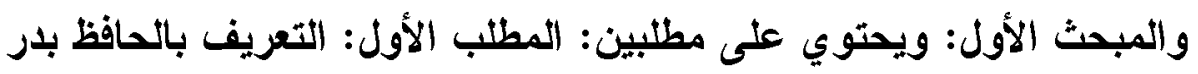
الدين العيني بذكر: مولده، ونثأته، ومكاتته العلمية، ومصنفاته، وسنة

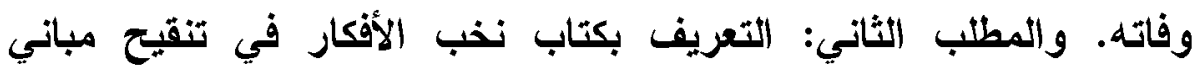


الأخبار في شرح معاني الآثار ، المبحث الثاني : طرق دفع إيهام التعارض

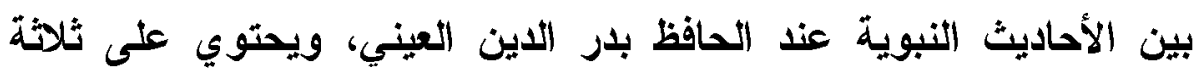

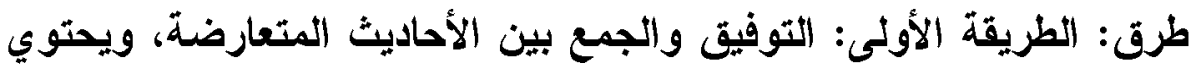

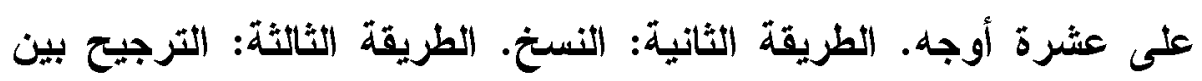

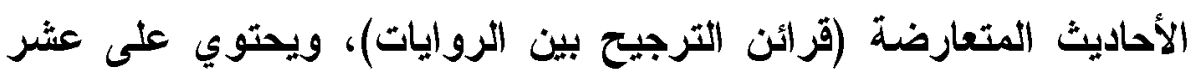

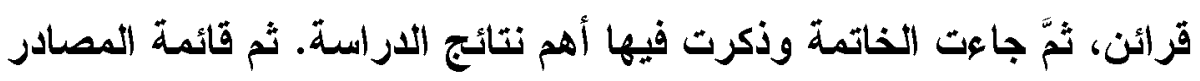
والمراجع. الكلمات المفتاحية: الحديث - التعارض - العيني - معاني الآثار - الحافظ

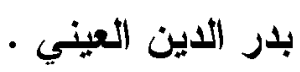




\title{
Methods of refuting the illusions of contradiction between the hadith (tradition) of the prophet for Al- Hafiz Badr Al-Din Al-Aini \\ Through his book "The elites of thoughts in emendation structure of reports in explaining the meaning of narrations"
}

\begin{abstract}
Ahmed bin Hassan Al Amer Al Asiri
Department of Islamic Studies - Faculty of Science and Arts in Mahayel Asir - King Khalid University - Kingdom of Saudi Arabia
\end{abstract}

Email: ahalaseeri@kku.edu.sa

\section{Abstract}

The subject of the contradiction and preponderance between Sharia (lawful) evidence in general and hadith (tradition) narratives in particular manifests the Sharia (law) in its real aspect and that it is like the clear destination as its night as its day that has no real contradiction. Yet, this contradiction is from the point of view of the assiduous, therefore this study came to confirm and clarify that. The research relies on the inductive approach in collecting scientific material by tracking and collecting the qualities of the methods of Al-Hafiz Badr al-Din al-Aini in refuting contradiction among the hadiths (traditions) of the Prophet in his book "The elites of thoughts in emendation structure of reports in explaining the meaning of narrations" then selecting examples that fit the research requirements. The research consists of an introduction that includes the 
importance of the study, the reasons for choosing the topic, the study approach. The first topic: contains two requirements: The first requirement is introducing Al-Hafiz Badr Al-Din Al-Aini by mentioning his birth, his upbringing, his scientific position, his works and the year of his death. And the second requirement is introducing the book "The elites of thoughts in emendation structure of reports in explaining the meaning of narrations"

The second topic is the: Methods of refuting the illusions of contradiction between the hadith (tradition) of the prophet for Al-Hafiz Badr Al-Din Al-Aini which contains three methods: The first method is: conciliation and combining the contradictory hadiths (traditions) and it contains ten aspects. The second method is: copying. The third method is: the weighting between the contradicting hadiths (traditions) (evidence of weighting between the narrations) and it contains ten clues. Then came the conclusion in which mentioned the most important results of the study with the list of sources and references .

Keywords: Hadith (tradition), Contradicting, Al Ain , Meanings of Archeology, Al-Hafiz Badr Al-Din Al-Aini (name) . 


\section{بسم الآه الرحمن الرحيم \\ الاقدهمة}

الحمد لله رب العالمين، والصلاة والسلام على سيد المرسلين، ورحمة

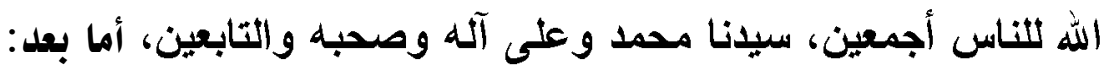

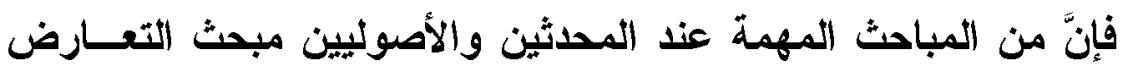
والترجيح، أو مختلف الحديث عند المحاثين المتقدمين، وتظهر أهمية هـــا

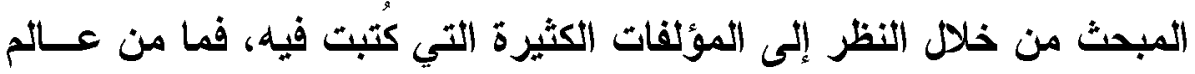
كتب في علوم الحديث وأصول الفقه؛ إلا وأفرد بابًا من أبواب مصنفه للحديث الميث

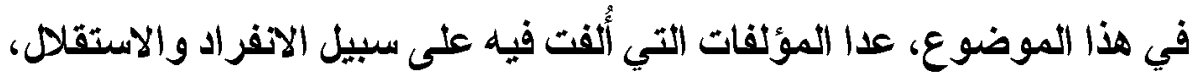

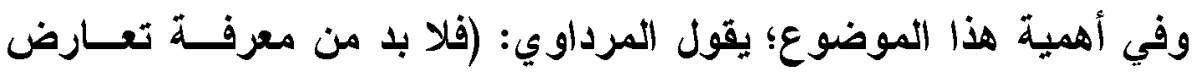

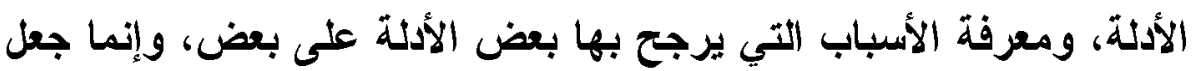

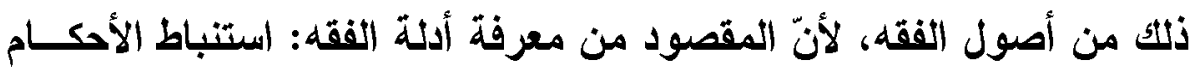

منها، ولا يمكن الاستنباط منها إلا بعد معرفة التعارض و الترجيح) (").

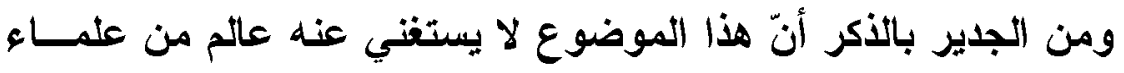

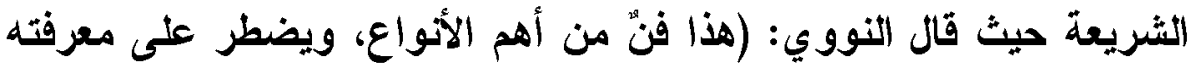

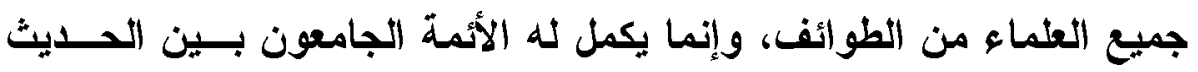

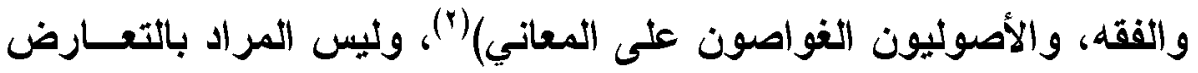

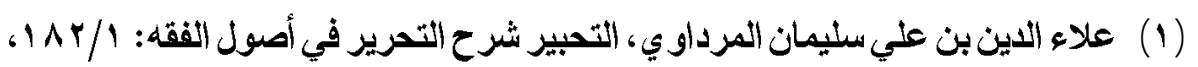

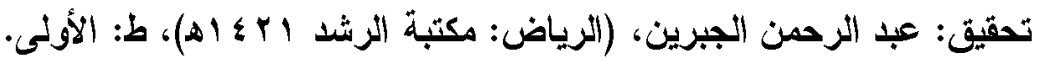

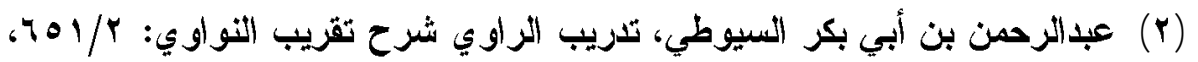

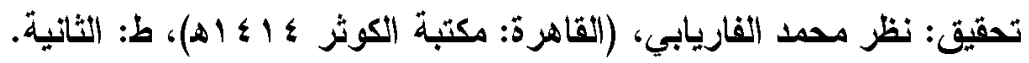


بين الأدلة، التعارض الحقيقي بين الأدلة الثرعية الصحيحة، لأنَّ هذا النوع

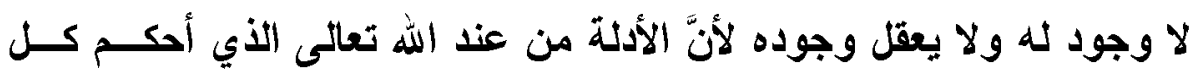

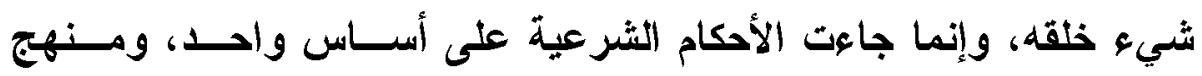

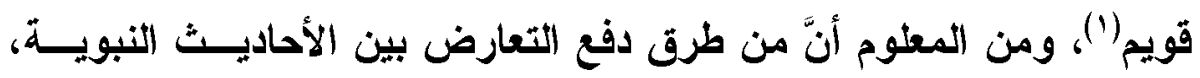

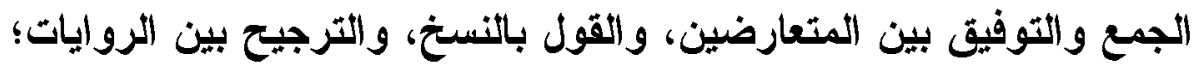

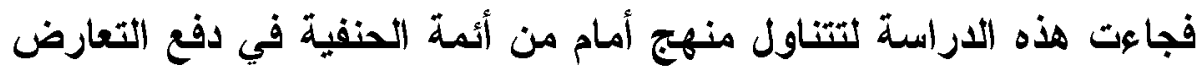
بين الأحاديث؛ وهو الإمام الحافظ بلدر الداين العيني. أهسية الدراسة:

إنَّ موضوع التعارض والترجيح بين الأدلة الثرعية عمومًا، والروايات

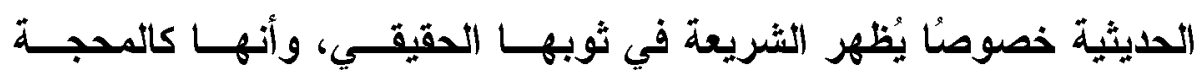

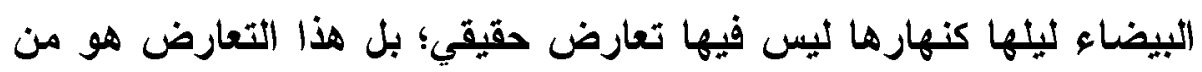

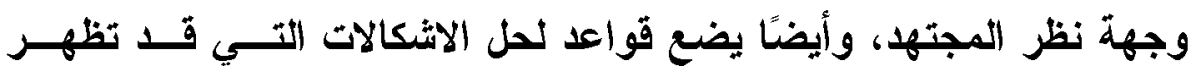

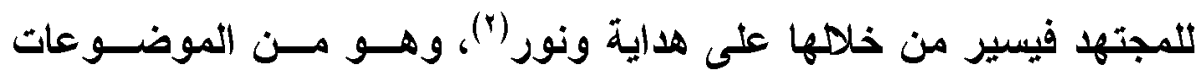

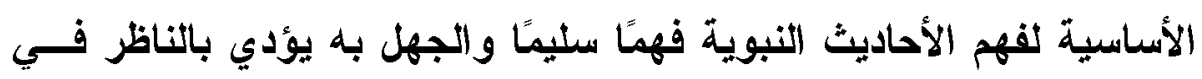
مختف الحديث إلى التخبط، وعدم الوصول إلى الحكم الصحيح فهو من أهم

(1) محد مصطفى الزحيلي، الوجيز في أصول الفقه الإسلامي: r/. 1ا؛؛ (دمثق: دار

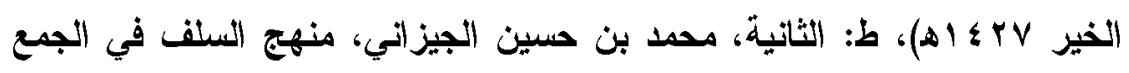

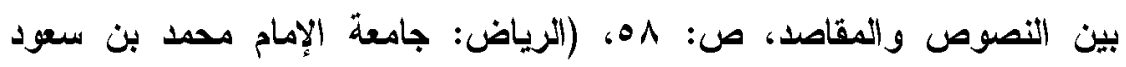

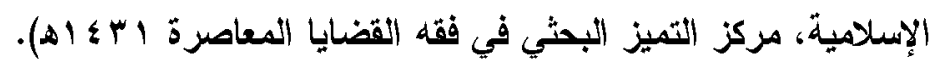

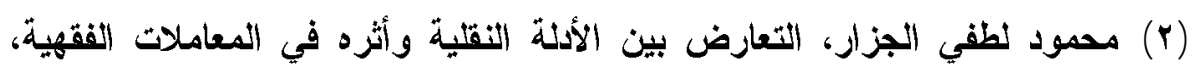

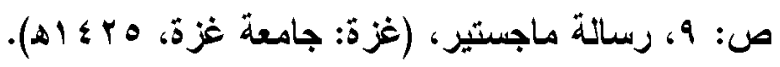


العلوم التي نحتاج إلى معرفتها، ومما يُبين أيضًا أهمية الدراسة أنها تثناول

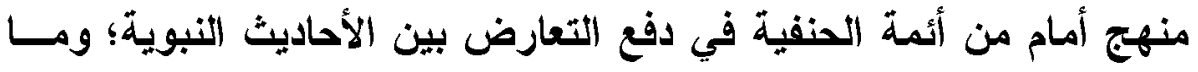

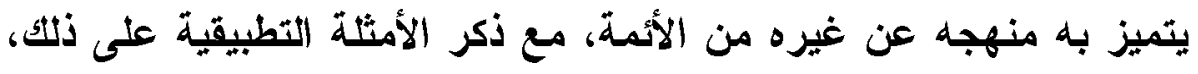

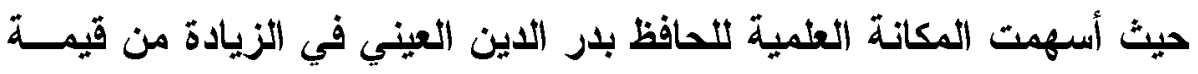
هذه الدراسة العلمية.

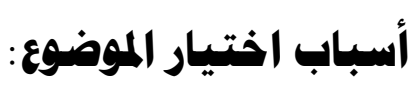

1- بيان أن التعارض في الأدلة الحايثية تعارض ظاهري صوري فقط من وجهة نظر المجتها؛ وأنه لا يوجد تناقض في الثريعة الإسلامية. r- منزلة الحافظ بلر الاين العيني العلمية.

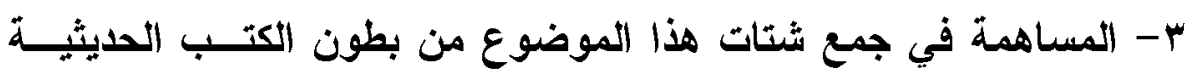
و الفقهية.

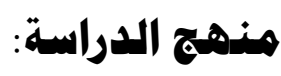

المنهج الاستقرائي في جمع المادة العلمية، من خلال تتبع وجمع معالم

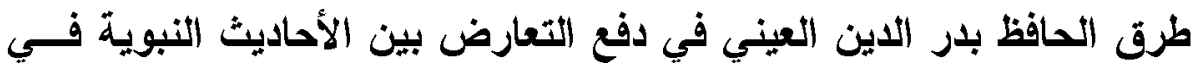
كتابه نخب الأفكار، ثُم انتقاء الأمثثة التي تناسب مقائ مقتضى البحث.

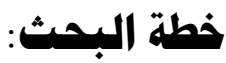

يتكون هذا البحث من مقدمة، ومبحثين، ثم الخاتمة، وفهرس المصادر والمراجع، وقا جاءت على النحو الآتي:

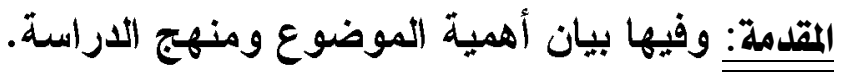

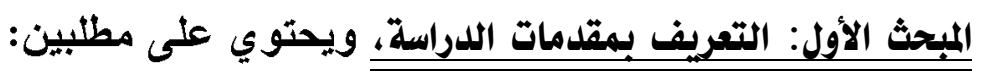
المطلب الأول: التعريف بالحافظ بدر الدين العيني. 
المطلب الثاني: التعريف بكتاب نخب الأفكار في تنقيح مباني الأخبار في

$$
\text { شرح معاني الآثثار . }
$$

المبحث الثاني: طرق دفع إيهاه التعارض بين الأحاديـث النبويـة عند الحـافظ

العيني، ويحتوي على ثلاثة طرق:

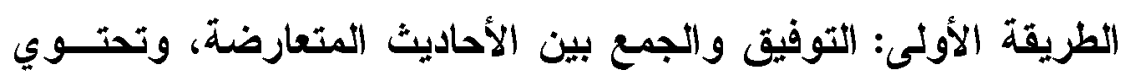

$$
\text { على عشرة أوجه: }
$$

الوجه الأول: التوفيق باختلاف المحل.

الوجه الثاني: التوفيق بحمل العام عثى الخاص.

الوجه الثائث: التوفيق بحمل المطلق على المقيد.

الوجه الرابع: التوفيث بحمل حديث التهي على الكراهة.

الوجه الخامس: التوفيق بحمل الأمر على الاستحباب لا نفي الجواز أو

الأوجوب.

الوجه السادس: التوفيق بالأخذ بالزيادة.

الوجه العابع: التوفيق بحمل أحد الحديثين على الرخصة والتخفيف.

الوجه الثامن: التوفيق بحمل أحد الحديثين على الخصوصية.

الوجه التاسع: التوفيق باختلاف الحال.

الوجه العاثر: التوفيت بحمل الحديث على نوع مــن أنـــواع الجمــع المعتبرة.

الطريقة الثانية: النسخ.

الطريقة الثالثة: الثرجيح بين الأحاديث المتعارضة (قرائن الترجيح بين

الروايات)، وتحتوي على عثر قرائن:

\section{$1 . \leqslant 0$}

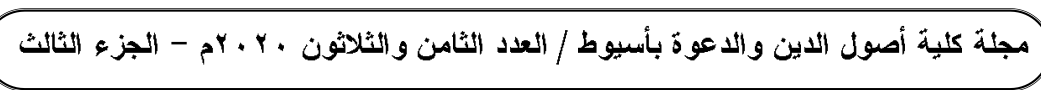


القرينة الأولى: الترجيح بصحة الحديث إجماثًا. القرينة الثانية: الترجيح بموافقة القرآن لأحد الأليلين. الثرينة الثالثة: الترجيح بتقديم الروايات المثبتة على الروايات النافية. القرينة الرابعة: الترجيح بكثرة الرواة للحديث من الصحابة. القرينة الخامسة: الترجيح باعتبار اتقان الراوي ضبطًا وحفظًا. القرينة السادسة: الترجيع باتصال السند. القرينة السابعة: ترجيح ما رواه الثيخان على غيرهما. القرينة الثامنة: ترجيع من أخبر عن مشاهدة وعيان على غيره. القرينة التاسعة: ترجيح رواية أهل المدينة. القرينة العاثرة: ترجيح ما سلم من الاضطراب.

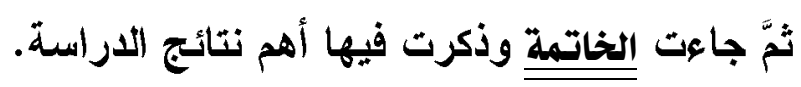
ثم فهرس المصادر والمراجع. 


\title{
المبحث الأول
}

\section{التعريف بالحافظ بدر الدين العيني}

وكتابه نفب الأفكار في تنقيح هباني الأخبار في شرح هماني الآثار

\author{
المطلب الأول \\ التعريف بالحافظ بدر الدين العيني
}

أولاً: هولده ونسبه ونشأته:

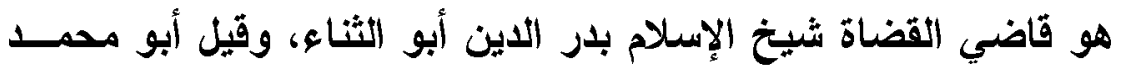

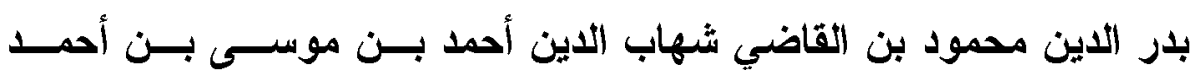

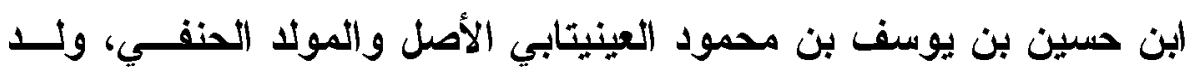

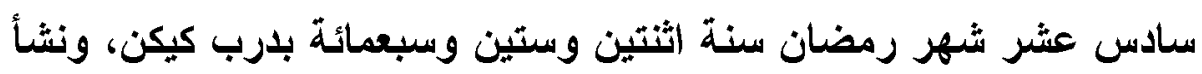

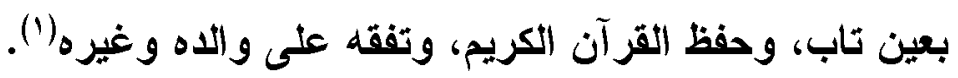

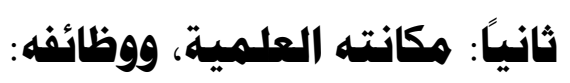

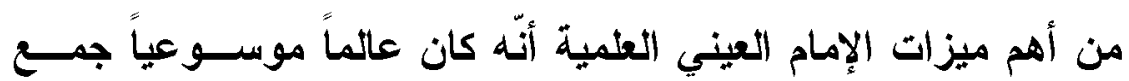

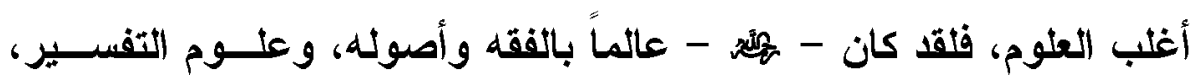

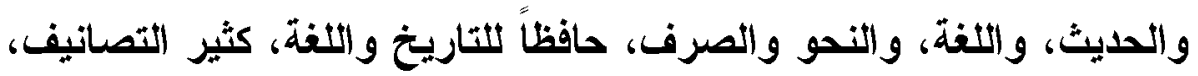

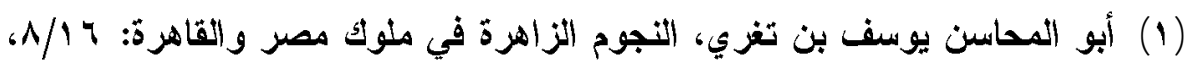

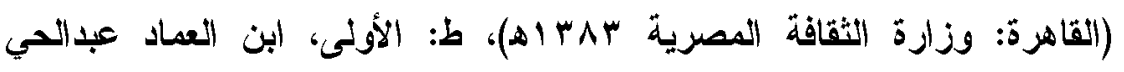

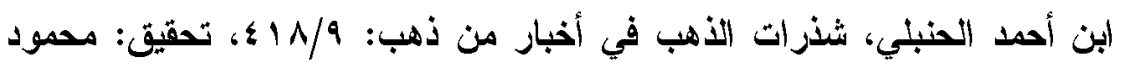

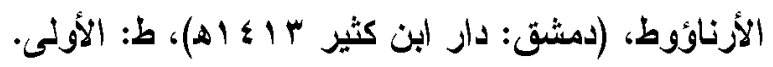




\section{وقد قيل إنه كتب الحاوي في ليلة، وكنلك القدوري|(').} وليَ في القاهرة الحسبة، وقضاء الحنفية، ونظر السجون، وتقرب من الملك المؤيد حتى عد من أخصائه، ولما ولي الأثرف سامره ولزمه، وكان يكرمه ويقدمه، ثَّ صرف عن وظائفه، وعكف على التدريس والتصنيف إلى التى

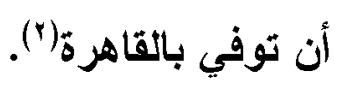

ثالثً: ومسنفاته:

يعتبر الإمام العيني من أكثر العلماء تأليفاً وتصنيفاً، حيث قـال عنــهـ تلميذه السخاوي: (وصنف الكثير بحيث لا أعلم بعد شيخنا تصــانيف أكثـر

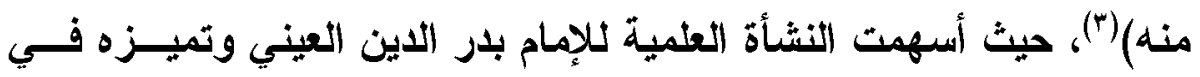
شتى الفنون إسهاماً كبيراً في كثرة مصنفاته وتتوعها، منها ما هو مطبوع ومحقق، ومنها ما هو مخطوط، نذكر منها:

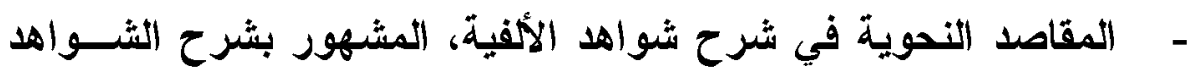

$$
\text { الكبرى (مطبوع). }
$$

- فرائد القلأد في مختصر شرح الشواهد (مطبوع).

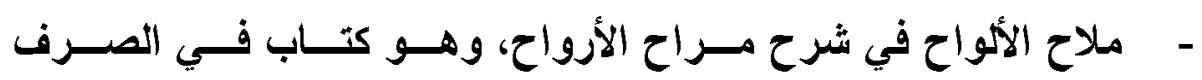
(مطبوع)

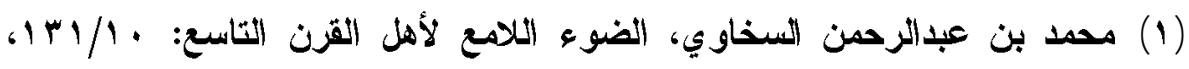

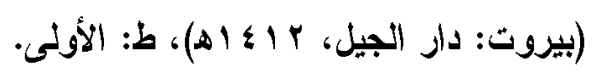

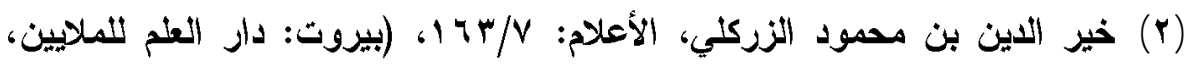

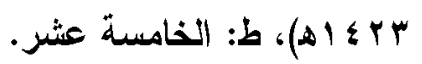

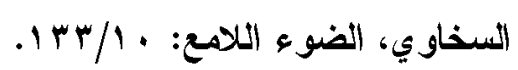

\section{$1 \cdot \varepsilon \wedge$}

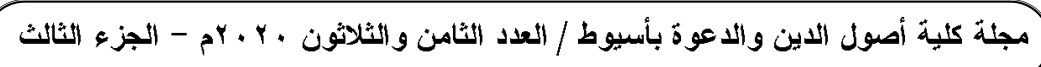


- ميزان النصوص في علم العروض (مفقود).

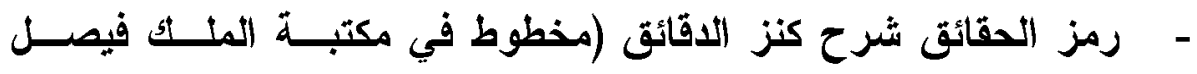

$$
\begin{aligned}
& \text { بالرياض). } \\
& \text { - البناية في شرح الهداية (مطبوع). } \\
& \text { - عمدة القاري شرح صحيح البخاري (مطبوع). } \\
& \text { - - شرح سنن أبي داود (مطبوع). }
\end{aligned}
$$

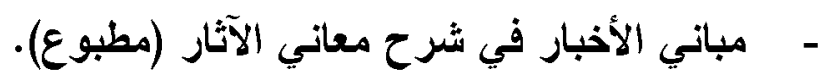

$$
\begin{aligned}
& \text { - - مثف القناع المرني عن مهمات الأسامي والكنى (مطبوع). } \\
& \text { - عقد الجمان في تاريخ أهل الزمان (مطبوع). } \\
& \text { رابعًا: وفاته: }
\end{aligned}
$$

توفي في القاهرة عام خمس وخمسين وثمانمائة من الهجــــة ليلـــة

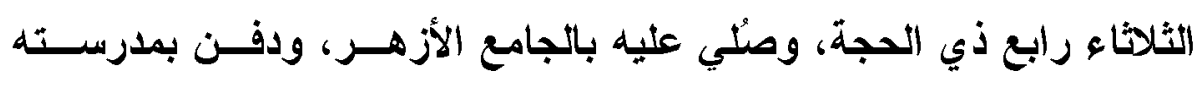

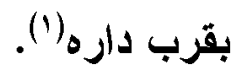

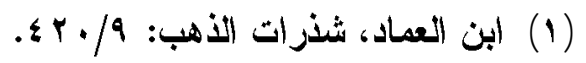




\section{المطلب الثاني}

\section{التعريف بكتاب نغب الأفكار في تنقيح هباني الأخبار}

\section{في شرح مهاني الآثار (1)}

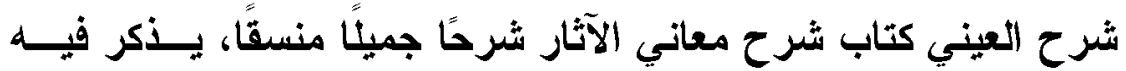
مناسبة الحديث بالباب، ومناسبة الباب بما قبله من الأبواب، ويتكلم علـى ملى رجال إسناده بإسهاب، ويبين فيه اللغــات والإعــراب، ووجـوه المعــاني والبيان، والأسئلة والاعتراضات والأجوبة، وتخريج مواضع الحديث، ومـــا يستنبط منه من الأحكام. وقد قام المؤلف: بوضع حرف "ص" قبل الجزء الأي بريا أن بشرحه من كتاب "ثرح معاني الآثار" دلامة على أنه من كلام المصنف أو إثـارة إلي أن هذا الكلام هو صدر الكتاب، كما يضع حرف "ش" قبل الثرح ثُم يبدأ في شرح الأبواب فيشرح ترجمة الباب وعلاقته بالباب الأبي قبله، وسبب تأخيره عنه.

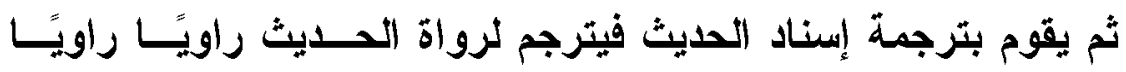
مقتصرًا على اسمه ونسبه ولقبه ومرتبته في الجرح والتعديل وذكــر مسن وثقه ومن جرحه، ومن أخرج له من أصحاب الكتب الستة.

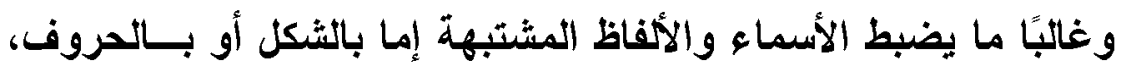
ثم يقوم بذكر من أخرج الحديث من أصحاب الكتب المشهورة، ثـــم يقــوم بالحكم على الأحاديث من حيث الصحة والضعف، ثم يشرع في شرح الألفاظ

(1) التعريف بكتاب نخب الأفكار في تنقيح مباني الأخبار في شرح معاني الآثار منقول

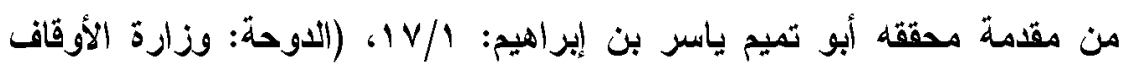

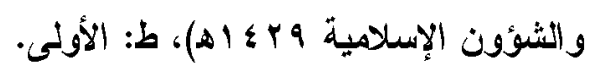


الغريبة في النص، وإعراب ما يثكل من الجمل والكلمات بإسهاب، ثم ينقل المصنف المذاهب الفقهية المتعلقة بالمسألة ويناقثها، ويتوسع فيها فيذكر آراء الصحابة والتابعين ويقية الفقهاء، ميع أدلتهم والردود عليها، وغالبًّا

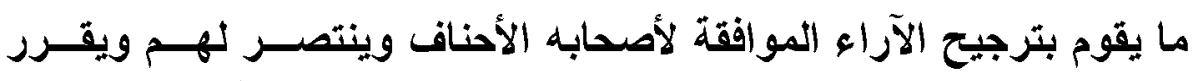

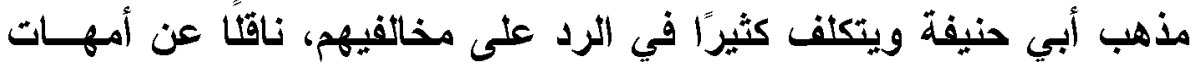
كتب الفقه والحديث، ويكثر من عرض الاعتراضات والإشكالات مبرزًا إياها

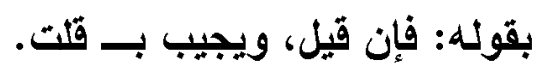
وغالبًا ما بذكر المصنف بعض وفئ الفوائد المنتقاة من الأحاديث في آخـر

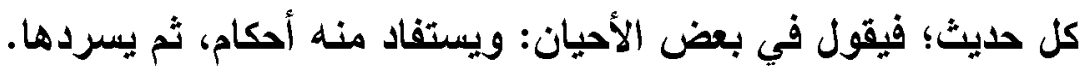

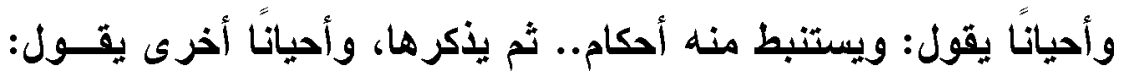

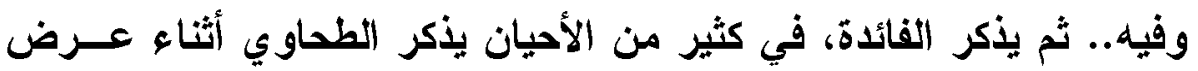

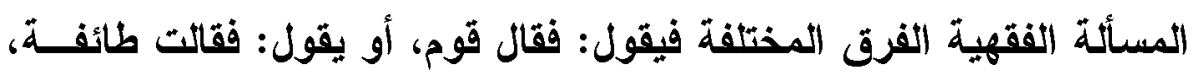

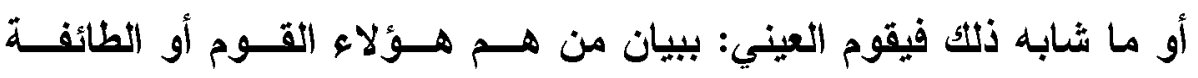

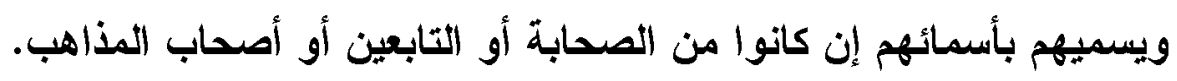

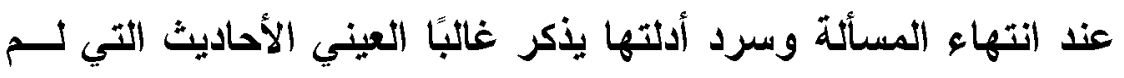

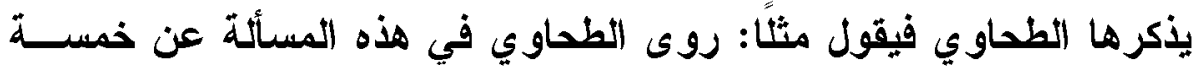

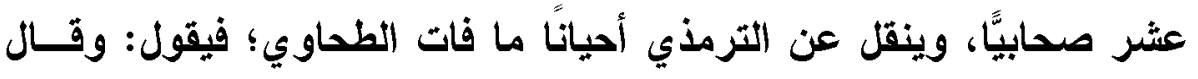

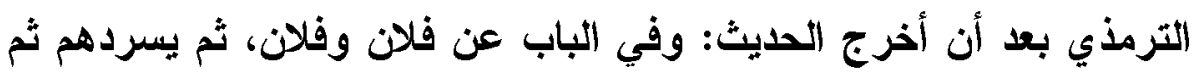

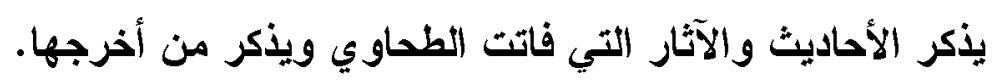

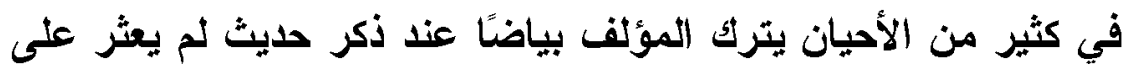

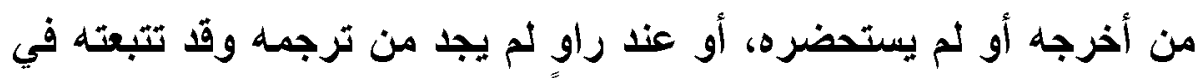
كثير من هذه المواضع واستدركتها. 


\section{المبمث الثاني}

طرق دفع إيهام التعارض بين الأحاديث النبـوية

\section{عند المافظ بدر الدين العيني}

\section{الطريقة الأولى: الجمهع بين الأحاديث المتعارضة بالتهفيق بينها:}

فكثيرًا ما يكرر الحافظ بلر الاين العيني: (أنَّ أصل العمل عند تعارض لهان الأخبار، التوفيث بينها؛ وذلكك لأنَّ الأصل في الأدلة الإعمال لا الإهمال) (")، وقال في موضع آخر : (والعمل بالكل بالتوفيق بينها أولى من العمل ببعضها وترك

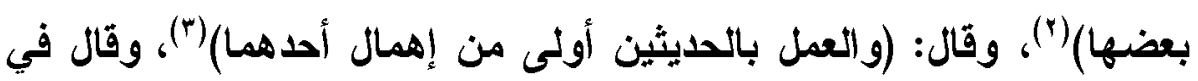
موضع آخر: (بل الوجه في مثل هذا الموضع أن تحمل هذه الآثار التي تجيء متعارضة على وجه لا يكون فيه التضاد ولا التخالف، وهذا هو الواجب؛ لما ها في ذلكك من حمل الآثار على التعادل والتوافق)(گ)، وقال في موضع آخــر : (إذ التوفيق بين الروايتين المتعارضتين هو الأصل)(॰). وهذا يدلنا علـى أنَّل الحافظ العيني يسلك في دفع التعــارض مســلك جمهــور الأصــوليين(")،

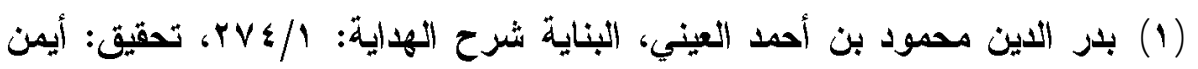
صالح شعبان، (بيروت: دار الكتب العمية ، بـ الهـ)، ط: الأوله.

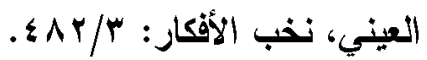

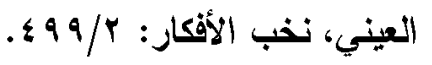

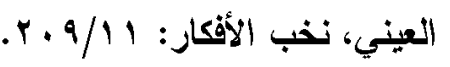

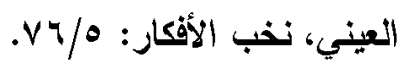

(7) عبد الله بن أحمد بن قدامة، روضة الناظر وجنة المناظر في أصول الفقه على مذهب الإمام أحمد بن حنبل، تحقيق: شعبان محد إسماعيل، (الزياض: مؤسسة 
والمحدثين('): الأين يقدمون الجمع على غيره، بخــلاف الأحنــاف الــنـين يقدمون النسخ على غيره(ن).

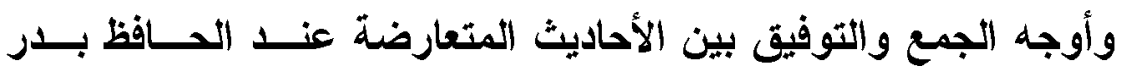
العيني في كتابه على الوجوه التالية: الوجه الأول: التوفيق باختلاف المحل:

ويستعمل غالباً في الجمع بين حديثين متعارضين لما في الالامة ويعبر

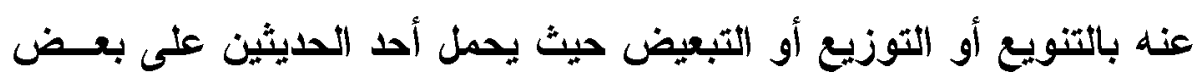

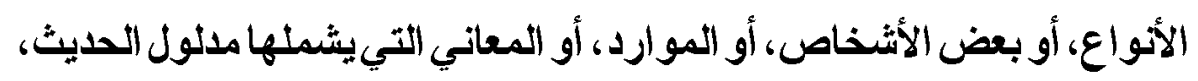

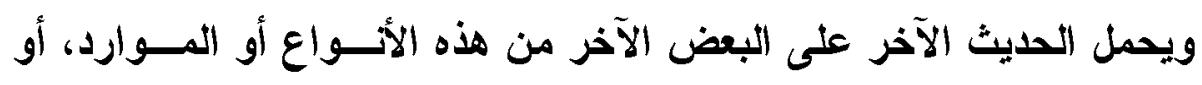

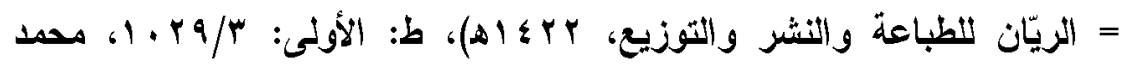

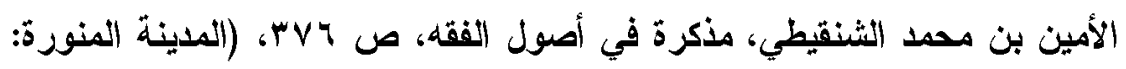

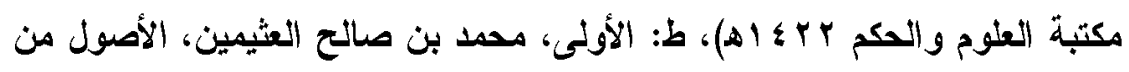

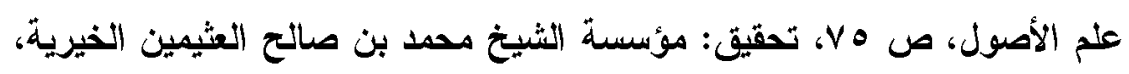

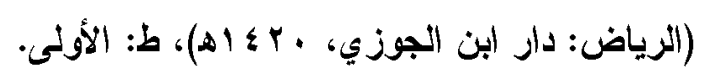

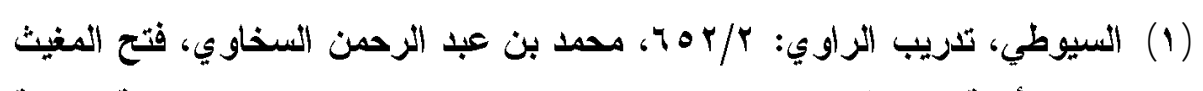

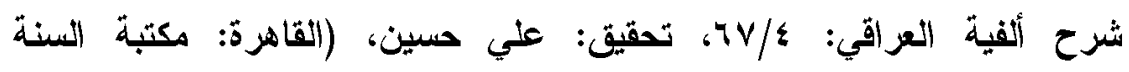

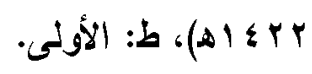

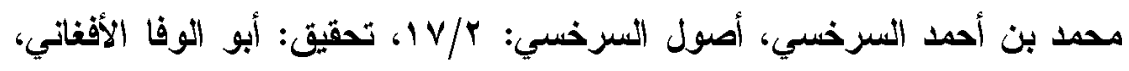

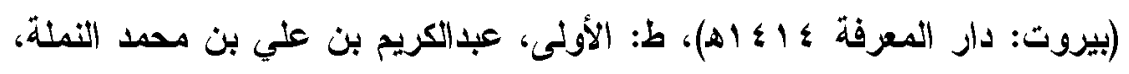

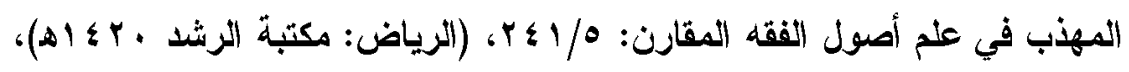

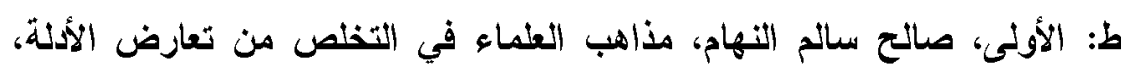

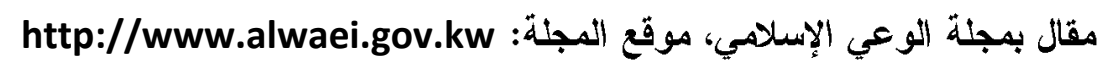


الأثخخاص، وذلتك بحسب القرائن التي تحف بالحديثين، والتي ترشـــ إلـى محل واحد من الحديثين، والجمع باختلاف المحل أو بالتبعيض أو بــالتتويع

كل هذه المصطلحات تعبير عن التوفيق بين المتعارضين باختلاف المحل (').

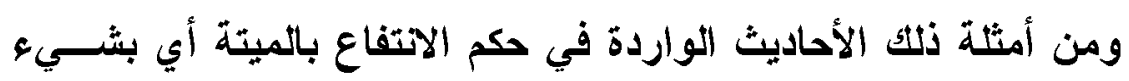
منها، يقول الحافظ بلر الاين العيني: (إثـارة إلى بيان وجه التوفيـث بـين

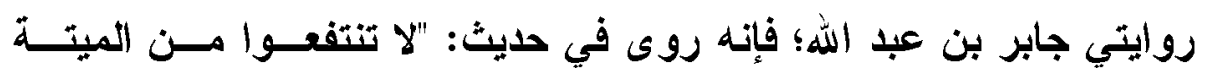

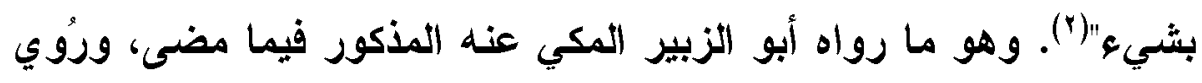

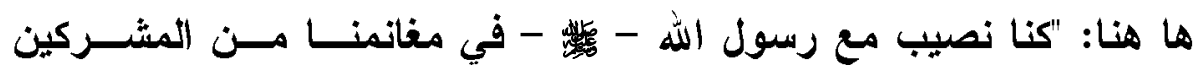

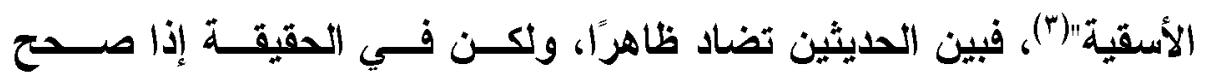
معانيهما بتفقان؛ لأن معنى حديثه الأول غير معنــى حليثـــه الآخــر، لأن

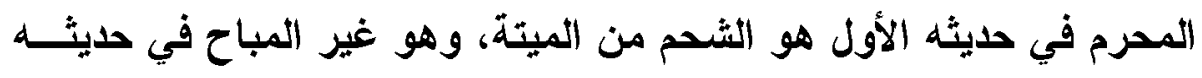

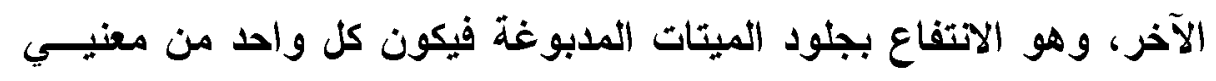

(1) عبد المجيد محد إسماعيل السوسوة، منهج التوفيث والترجيح بين مختلف الحديث

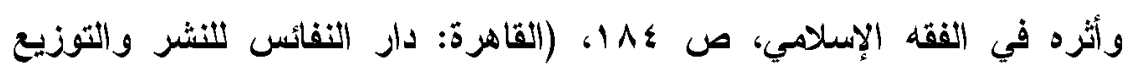

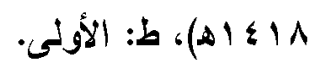

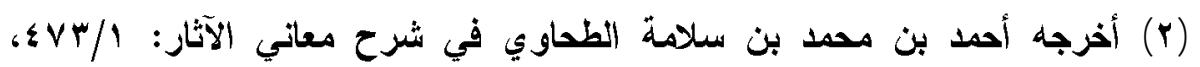

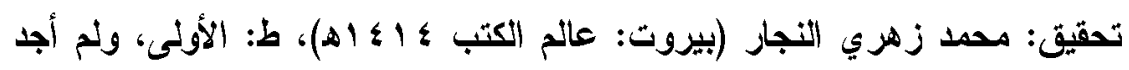

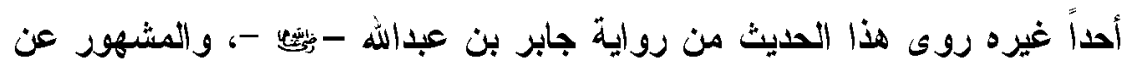

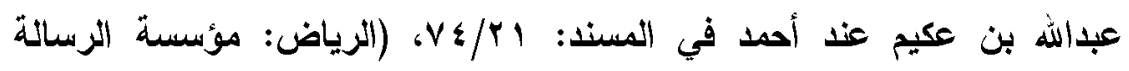

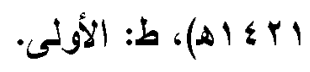

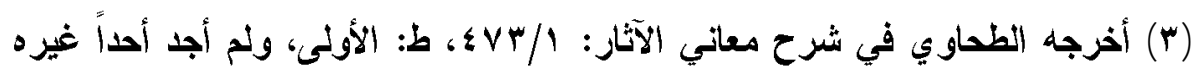
روى هذا الحديث. 
الحديثين في محل، فباختلاف المحل لا يتحقق التضاد)(") الوجه الثاني: التوفيق بحمل العام على الخاص:

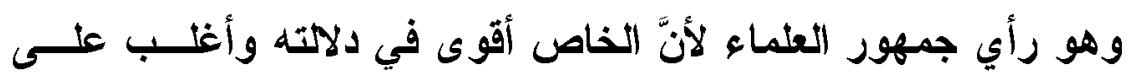
الظن لبعده عن احتمال التخصيص بخلاف العام فكان الأولى، ولأنَّ العمـلـل بالعام يلزم منه إبطال الاليل الخاص، أمَّا العمل بالخاص فلا يلزم منـه إبطال

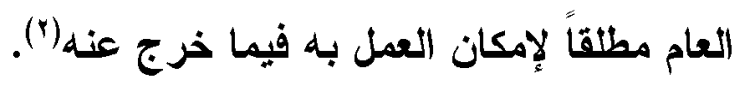
ولذا قال الحافظ بدر الاين العيني: (إذا ورد حديثان أحدهما عام والآخر خاص، فإن عُلمِ تقديم العام على الخاص خصَّ العام بالخاص، كمن يقهـول

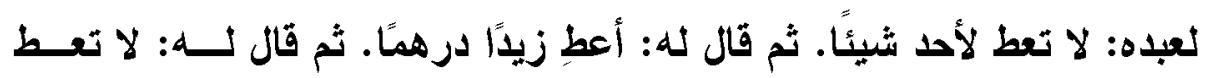

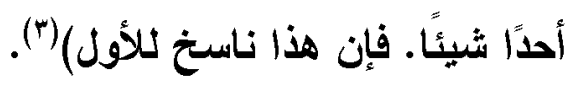
ومثالهه قول الحافظ العيني في الجمع بـين حسـيث: "جـرح العجمــاء

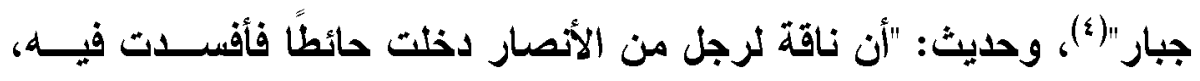

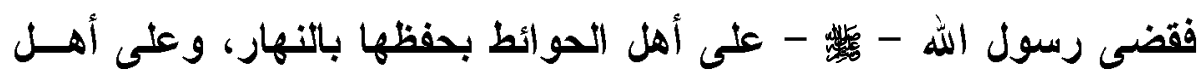
المواثـي ما أفسدت مواثيهم بالليل"(ه): (فان قيل: قال أبو عمسر : جعــــ

$$
\text { 19 العيني، نخب الأفكار: 190/V. }
$$

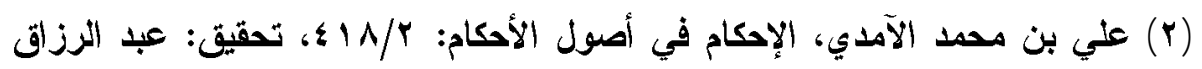

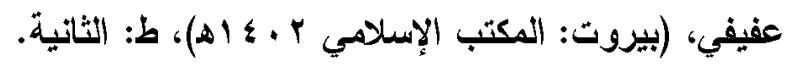

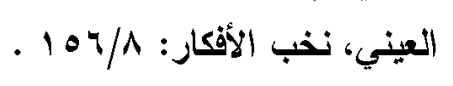

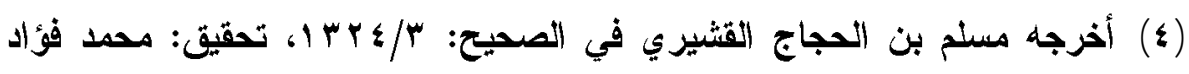
عبد الباقي (بيروت: دار إحياء التراث العربي)، ط: الأولى .

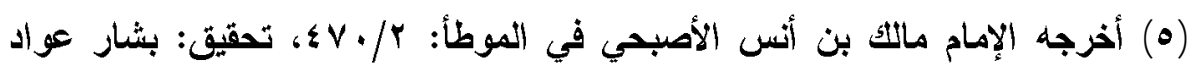

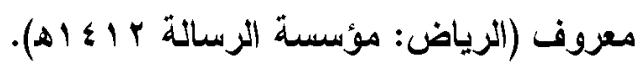


الحنفية حديث: "جرح العجماء جبار" معارضًا لحديث البراه، ولـيس كمــا زعموا وذهبوا إليه؛ لأن التعارض في الآثار إنما يصح إذا لم يمكن استعمال

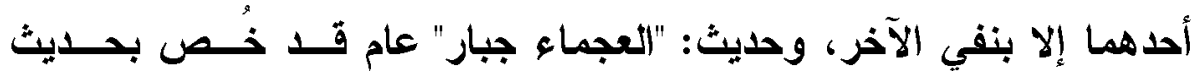

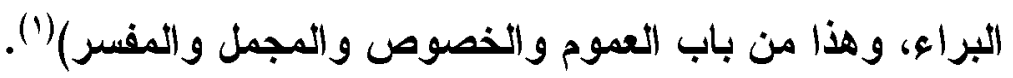
الوجه الثالث: التوفيق بحمل المطلق على المقيد:

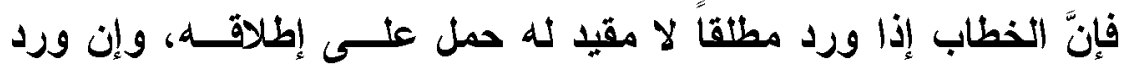
مقيداً حمل عثى تقييده، وإن ورد مطلقاً في موضع ومقيداً في موضع آخر مله فزلك على أقسام:

الأولٍ: أن يختفا في السبب والحكم، فلا يحمل أحدهما على الآخر بالاتفاق. الثاني: أن يتفقا في السبب والحكم، فيحمل أحدها على الآخر، وقد نقل الاتفاق في هذا القاضي أبو بكر الباقلاتي والطبري وغيرهما.

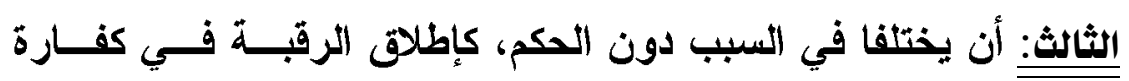
الظهار وتقيدها بالإيمان في كفارة القتل، فالحكم واحد وهو وجوب الإعتاق في الظهار والقتل مـع كون الظهار والقتل سببين مختلفين، فهذا القسم هــو موضع الخلاف)("). ومن أمثلتهله ما جاء في قتل الخمس الفواست؛ ومنها الغــراب؛ فتــال:

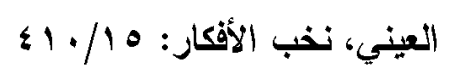

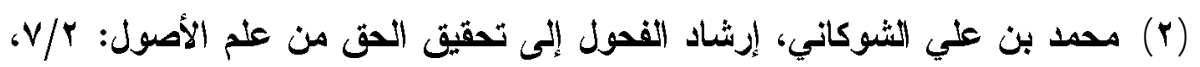

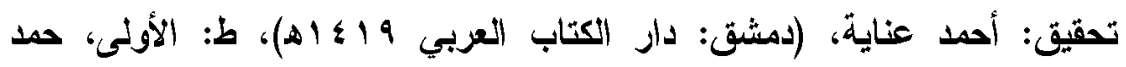

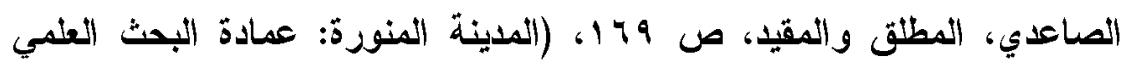

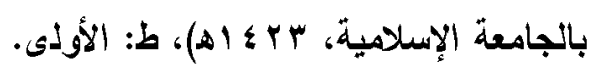


(روى مسلم عن ابن مثنى وابن بثـار، كلاهما عن محمد بن جعفـر، عـن شعبة، قال: سمعت قتادة بحدث، عن سعيد بن المسيب، عن عائشة، عـن فئن

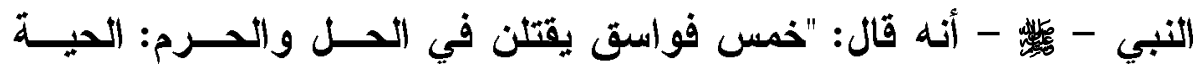

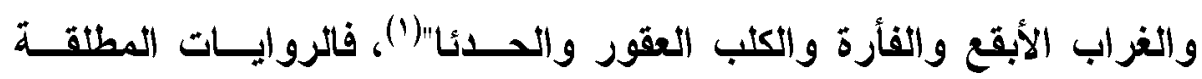
محمولة عثى هذه الرواية المقيدة، وذلك لأن الغراب إنما أبيح قتله لكونــهـ

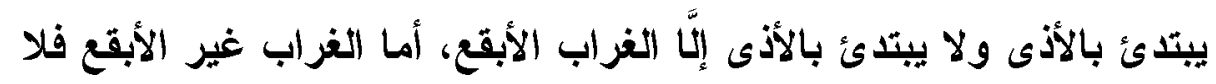

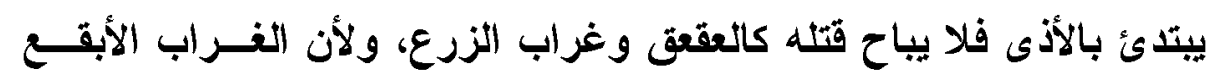
يأكل الجيف ويقع على وبر البعير وصاحبه قريب منه بخلاف غيره فإنه لا يأكل الجيف ... ثم قال عن الأحاديث التي اطلت الغراب بدون ذكر الأبةـــع

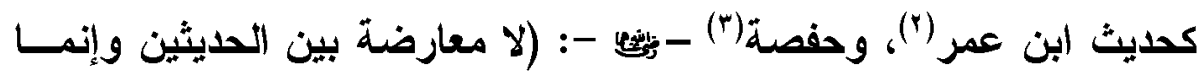
هما مطلق ومقيد، فحمل المطلق على المقيد كما ذكرنا)(عاء). الوجه الرابع: التوفيق بحمل حليث النهي على الكراهة:

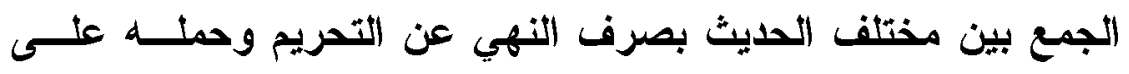
الكراهة يكون في حالة ورود حديثين: أحدها ينهى عن فعل شيء والآخر

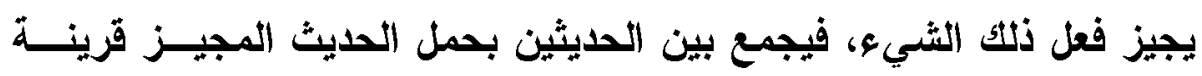

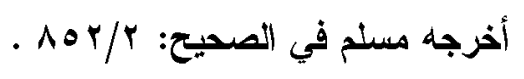

(Y) أخرجه أبو داود سليمان بن الأثنعث في السنن، تحقيث: محمد محي الاين: (Y)

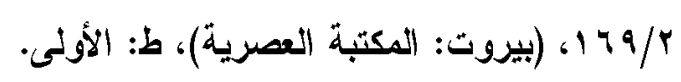

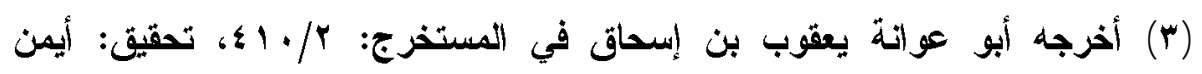

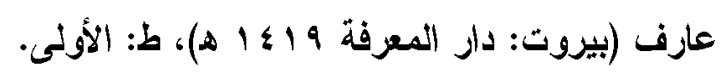

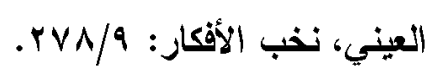


صارفة للنهي، وتجدر الإثـارة إلى أنَّ مسلثك الجمع بالحمل عثـى الكراهـــة مبني على أمرين: الأول: إنَّ ذلكـ من باب التأويل الأني فيه صرف للنهـي عن ظــاهره؛ وهــو التحريم إلى غيره بدليل وهو جائز عند العلماء، لأنه إذا كان يجوز صـرف النهي عن ظاهره بقرينة، فالأولى أن يصرف عن هاهره بده بدليل. الثاني: إنَّ الجمع بين الأحاديث بحمل النهي على الكراهة يستعمله العلمــاء كثيرأ للتوفيت بين الأحاديث(') ومثاله في التعارض الظاهر بين الأحاديـــ الواردة في حكم شرب الماء قائمًا وقاعدًا: (الأحاديث التي أخرجها عن ستة من الصحابة؛ فإنها تدل على إباحة الثرب قائمًا، وما رواه في أول الباب عن الجارود وأنس بقتضي كراهة ذلكك، وبينهما تعارض ظاهز ، والتوفيت بينهما: أن ما روي مما فيه الكراهة محمول على نهي الإثفاق لا التحريم)(مان. الوجه الخامس: التوفيق بحمل الحليث على الاستحباب والندب لا نفي الجواز أو الوجوب:

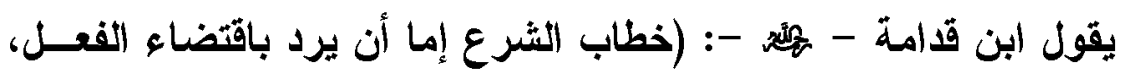

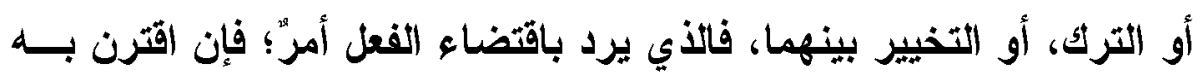
إثعار بعدم العقاب على الترك فهو ندب؛ وإلا فيكون إيجابًا)(ّا.

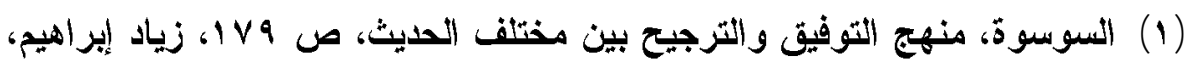

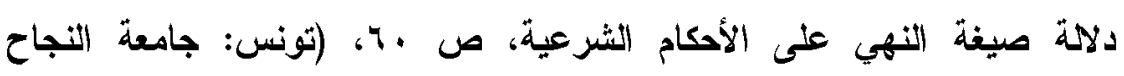

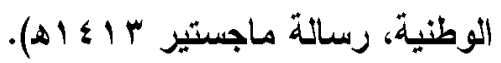

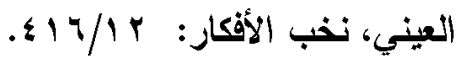

ابن قدامة، روضة الناظر: 9V/1، محد بن الطيب الباقلآي، التقريب والإرشاد،

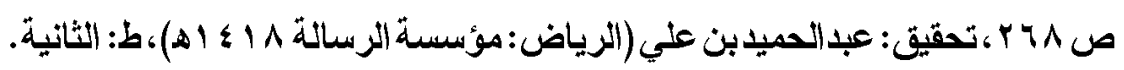


فتبين من الكلام السابق أن مبنى ذلتك عثى استقراء نصوص الثــرع

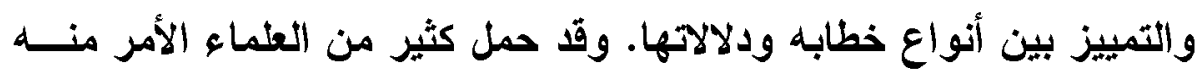
مجردة عن القرائن بل احتف بها ما يصرف الحكم عن الوجوب إلى غيره.

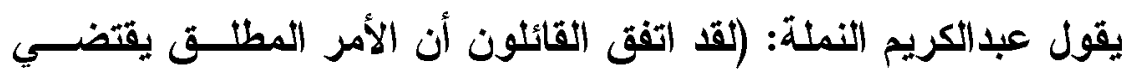

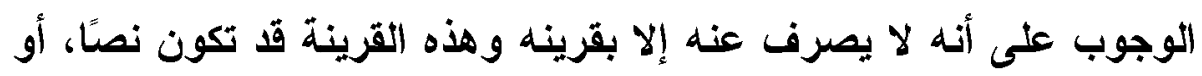

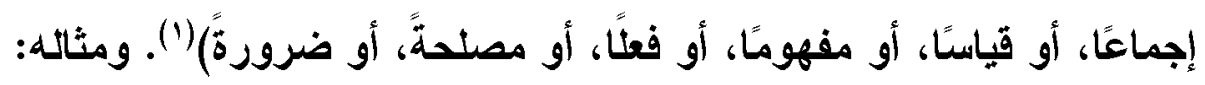

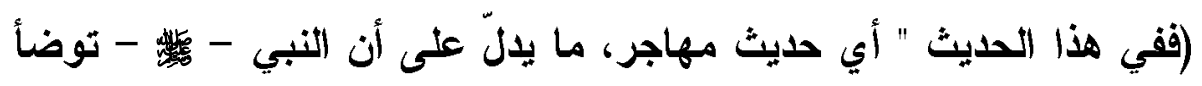

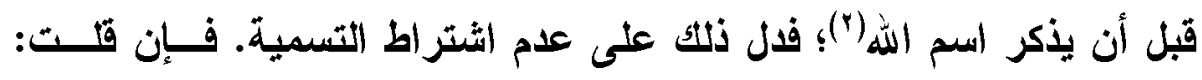

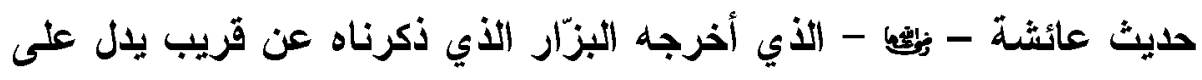

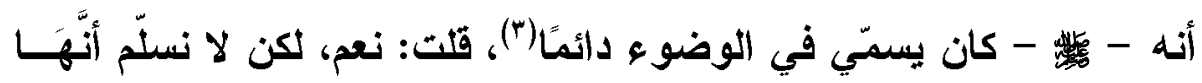

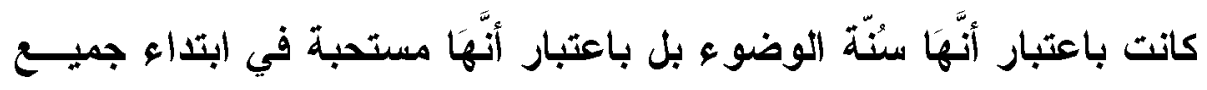

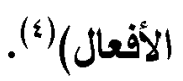

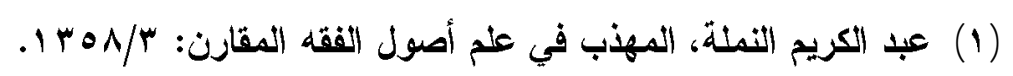

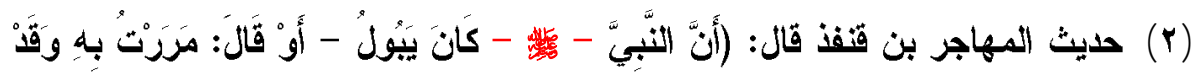

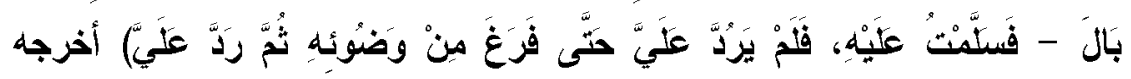

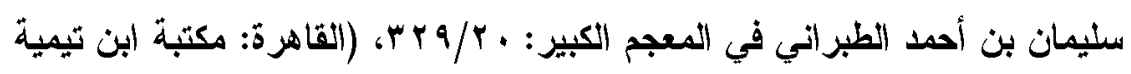

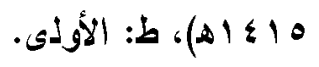

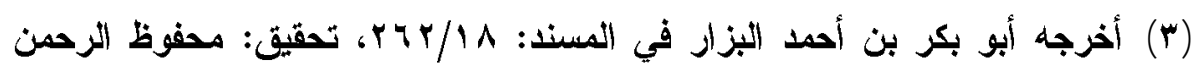

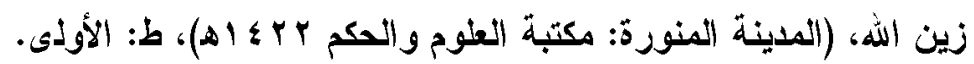

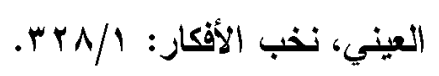




\section{الوجه السادس: التوفيق بالأخذ بالزيادة:}

وذلكت إذا ورد حديثان وكان في أحدهما زيادة ليست في الآخر، وكـــان

الزيادة غير منافية للمزيد عليه، فيجمع بينهما بالأخذ بالحديثين فيما التقيا

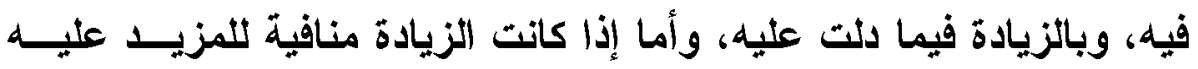
فيصار إلى الثرجيح(')

ومثالكه في نخب الأفكار: (فإن قيل: قال الثيهقي: قال الثـافعي: ســمعنا بعض أهل العلم يقول: نخاف ألا يكون محفوظًا، ثُم استلال الثافعي على ذلت

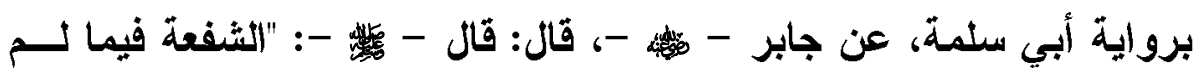
يقسم، فإذا وقعت الحدود فلا شفعة"(r)، قال: وروى أبو الزبيز عـن جـابر

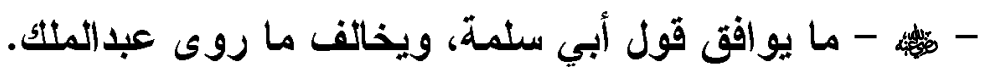
قلت: في حديث أبي سلمة، عن جابر زيادة؛ وهي قولـــه: "وصــرفت الطريق"، كما رواه البخاري عن محمَّد ابن محبوب، عن عبد الواحـــ بـن زياد، وهثام بن يوسف، عن معمر، عن الزهري، عن أبي سلمة،، عن جابر

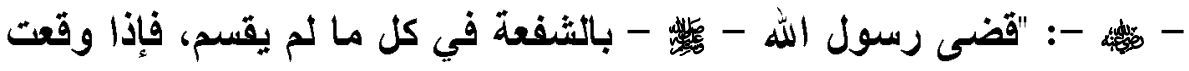

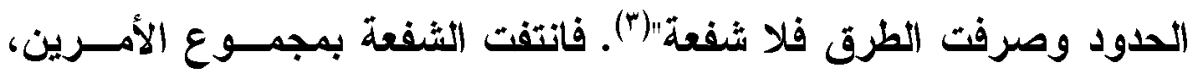

(1) إبراهيم شوقار، تعارض الأدلة الشرعية في الفكر الإسلاهي، ص اكـا، (بيروت:

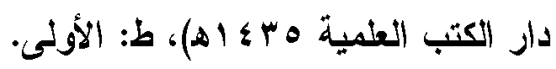

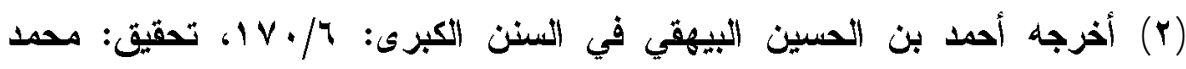

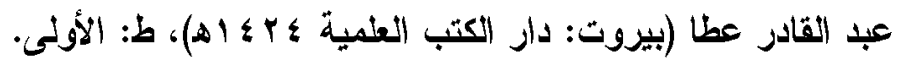
(r) أخرجه محمد بن إسماعيل البخاري في الصحيح: مV/r/

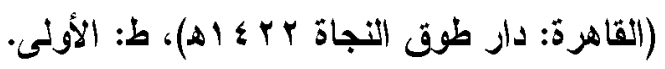


فمقتضاه أنه إذا وقعت الحدود وكان الطريق مشتركًا لا تثبت الشفعة، فيثبث

بذلك أن الحديثين متفقان لا مختلفان) ("). الوجه السابع: التوفيق بحمل أحل الحديثين على الرخصة والتخفيف: فالرخصة أصلها التخفيف عن المكلف ورفع الحرج عنه؛ حتى يكـون من ثُلل التكليف في سعة واختيار بين الأخذ بالعزيمة والأخذ بالرخصة(؟).

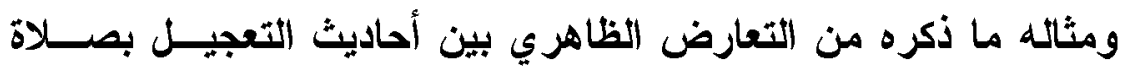

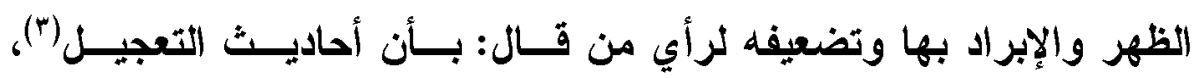
منسوخة بأحاديث الإبراد(§): (هذا السؤال برد عثى ما ذكر من ثبوت النسخ

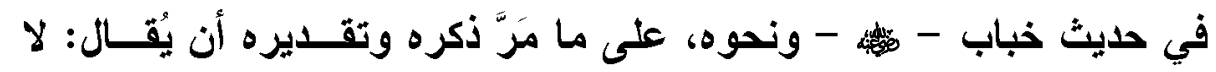

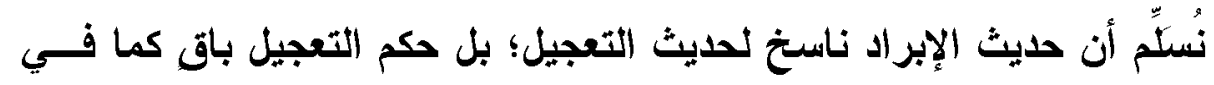
حديث خباب ومن ذكر معه، وإنما كان أمره -

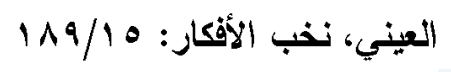

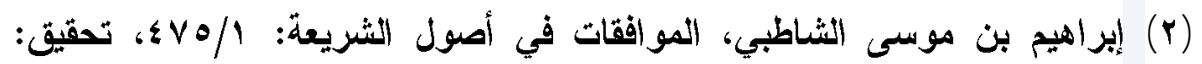

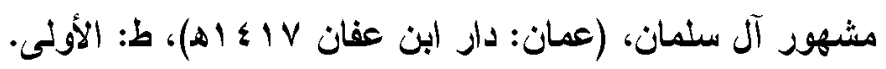

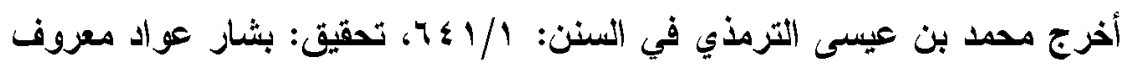

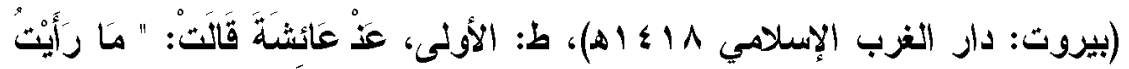

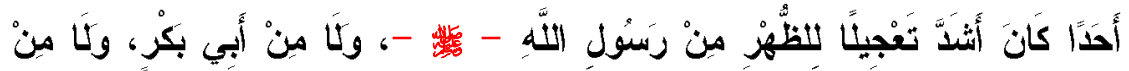

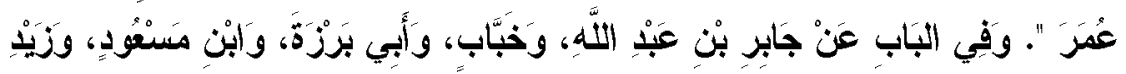

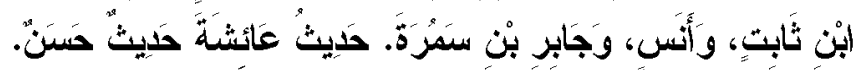

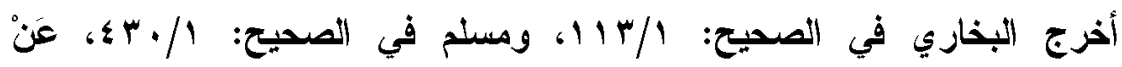

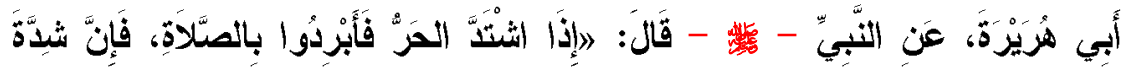

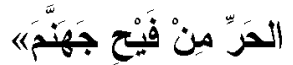


لهم؛ لأجل شدة الحر لأن مسجدهم لم يكن له ظلا، وكانوا يتضررون وقت

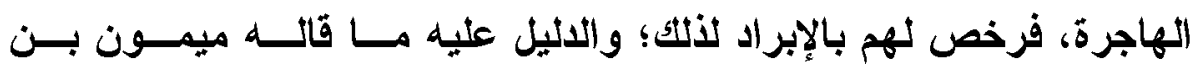

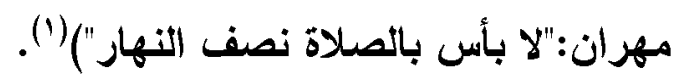

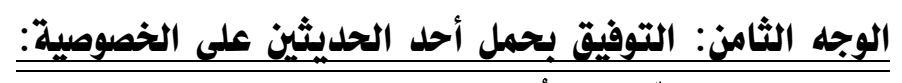

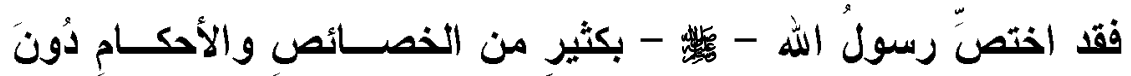
أمتِهِ؛ تكريماً لهه وتبجيلاً. ومثأله ما ذكره الحافظ العيني في الجميع بين الأحاديث القولية الدالة على التى

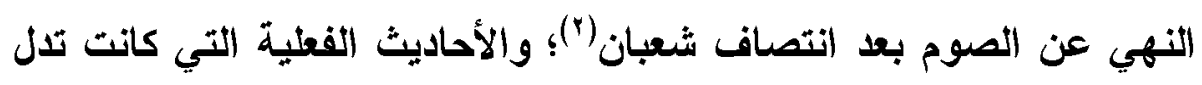

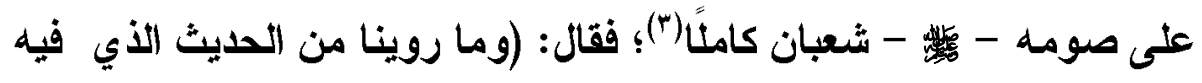

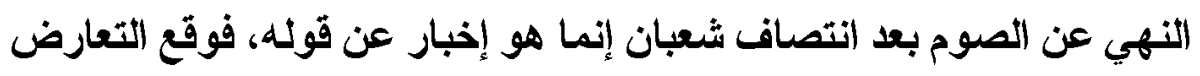

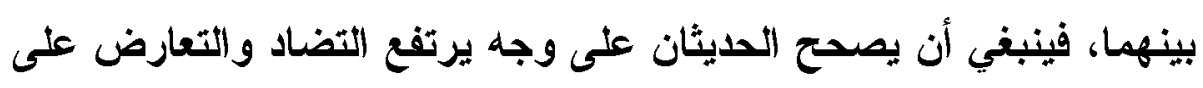

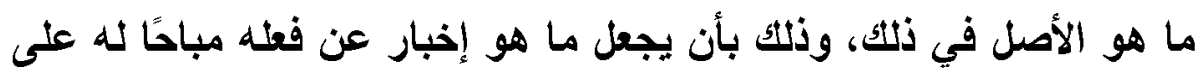

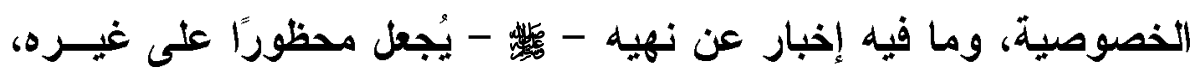

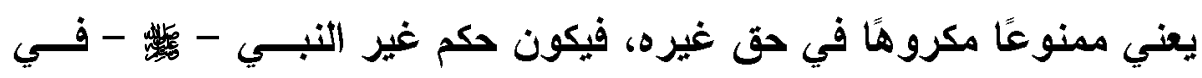

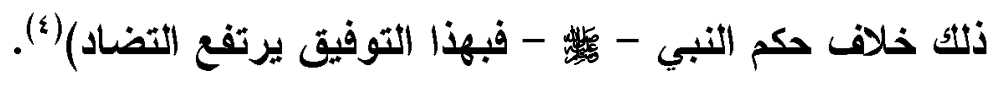

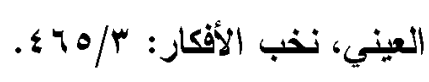

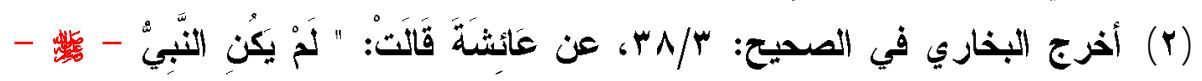

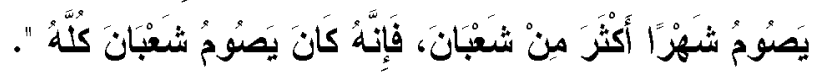

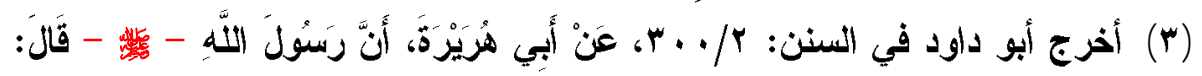

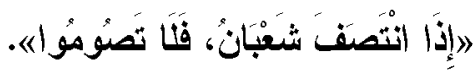

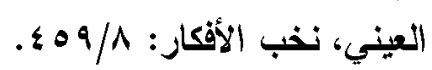




\section{الوجه التاسع: التوفيق باختلاف الحال:}

فعندما بتعارض حديثان محكمان في شيء واحد فيجمع بينهما بتنزيـلـل كل واحد منهما على حال غير حال الآخر، فيرتفع التعارض بين الحكمــين

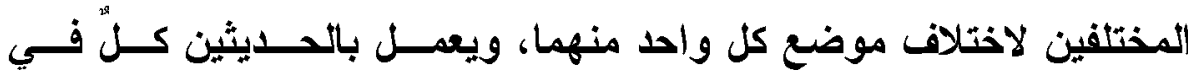

موضعد|(1)

ومثالهه عندما ذكر الآثار الواردة - والتي ظاهرها التعــارض - فـي

كيفية غسل وصلاة المرأة المستحاضة؛ قال: (واعلم أن المستحاضات على

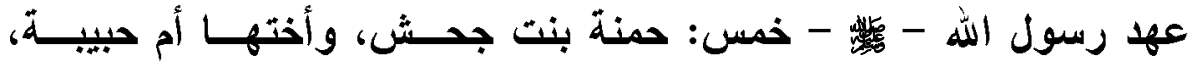
وفاطمة بنت أبي حُبيش القرشية الأسدية، وسهلة بنت ســهيل القرشـية،

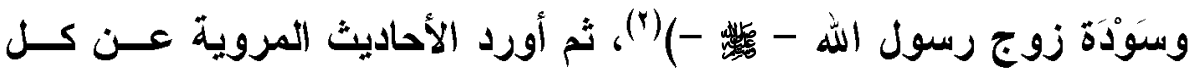
واحدة منهن واختلافها عن الأخرى في غسلهن من الاستحاضة والصــلاة، ثم قال: (ملخص هذا الوجه أن يحمل كل حديث ورد في هذا الباب على وجه من الوجوه، فلا يبقى بينها لا تعارض ولا اختلاف، وهذا هو التوفيق فيمــا بينها؛ وليس فيه لا نسخ، ولا نظر إلى التقليم والتأخيز)("). الوجه العاشر: التوفيق بحمل الحليث بـي نوع من أنواع الجمع المعتبرة: وهذا هو الأصل في التعامل مع الأحاديث التي ظاهرها التعارض؛ فــان

(1) عبد المجيد بن محد إسماعيل السوسوة، مباحث في المقاصد والاجتهاد و التعارض

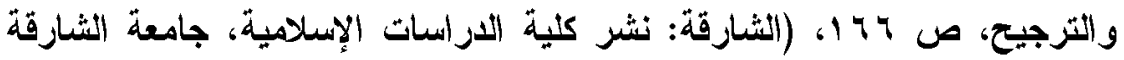

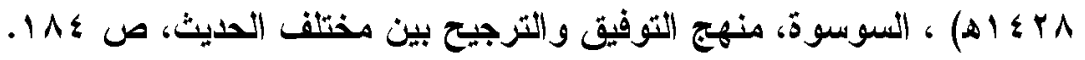

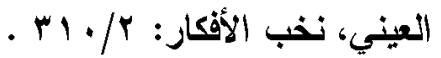

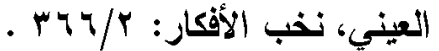




\section{العمل بهما أولى من إسقاط أحدهما بالكلية(1).} ومثال ذلتو قوله في التوفيق بين الأحاديث الواردة في حكـم القصــر للمسافر المقيم في مصر: (إثثارة إلى وجه التوفيـث بـين روايـــة حيّـان

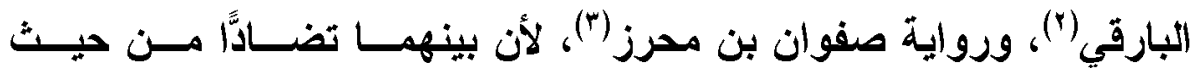

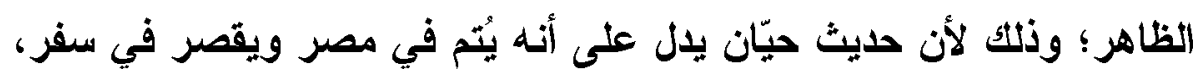
وحديث صفوان مطلق بال على أن المسافر بقصر سواء كان في مصــر أو لون سفر، ووجه التوفيق: أن حديث صفوان محمول على الصــلاة فـي غيـر

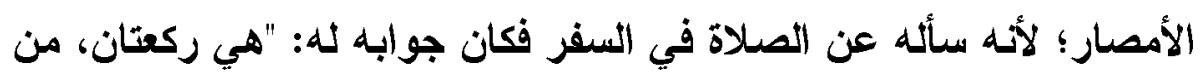
خالف السنة فقد كفر" وحديث حيان البارقي محمول على صــلاة المســافر

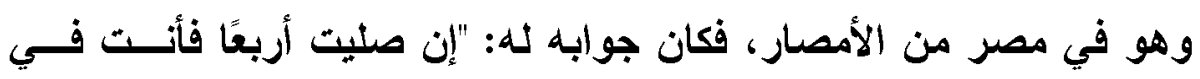
مصر، وإن صليت ركعتين فأنت مسافر"، فافهم)(ؤ).

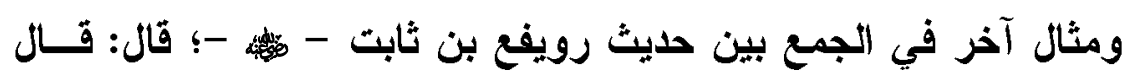

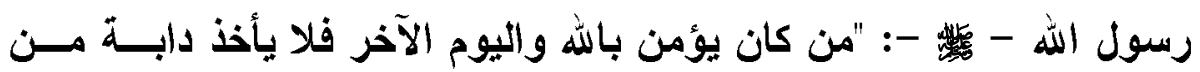

محد إبراهيم الحفناوي، دراسات أصولية للسنة التبوية، ص •ـ، (القاهرة: دار

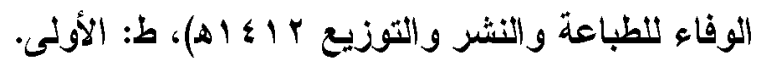

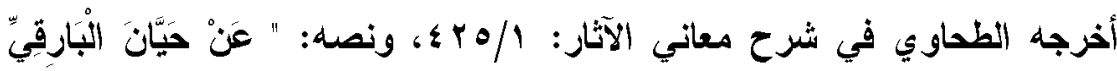

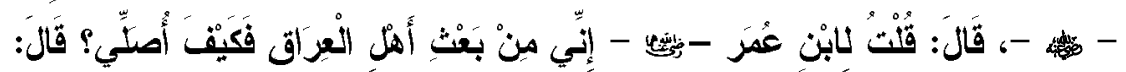

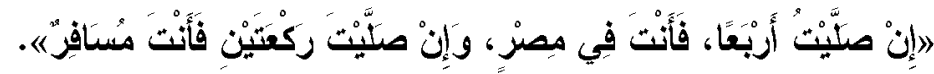

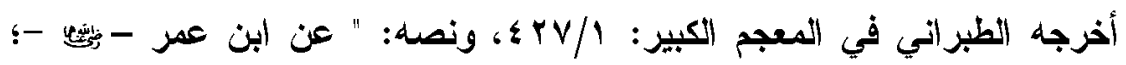

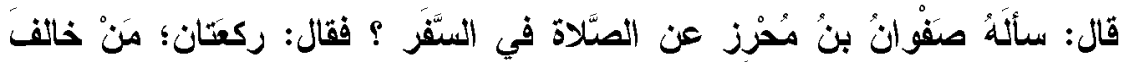

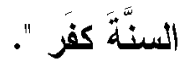

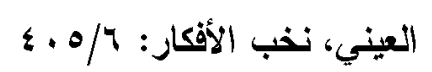


المغانم فيركبها حتى إذا أنقضها ردَّها في المغنـانم "(') وحــيث عبـــ الله

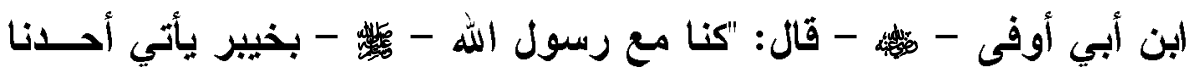
إلى الطعام من الغتيمة فيأخذ منه حاجته"(r).

قال الحافظ بدر الاين العيني: (وإلى بيان مجمل الحديث الأي احتجــوا

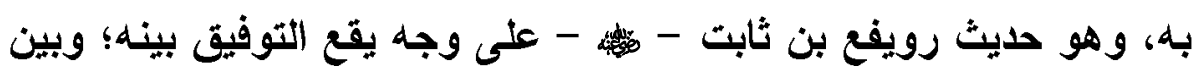

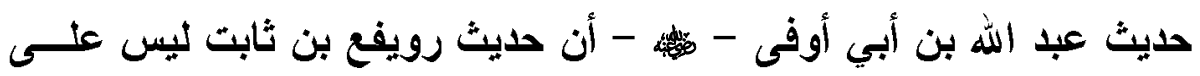
إطلاقه؛ حثى لا يعارضه حديث ابن أبي أوفى، وإنما هو محمول عثى مسن يستعمل السدلاح وهو غني أو يستعمله على وجه الخيانة)(rآ. الطريقة الثانية: النسخج (ولا يُمار إلى النسخج إلا بعد تعذر البمع):

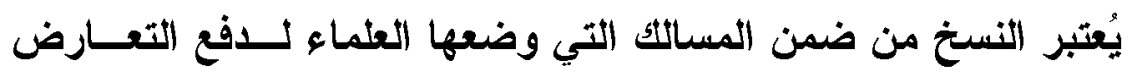

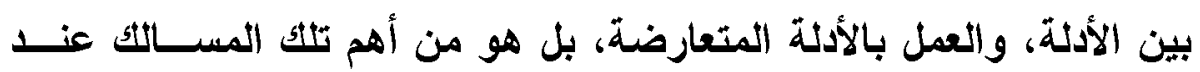

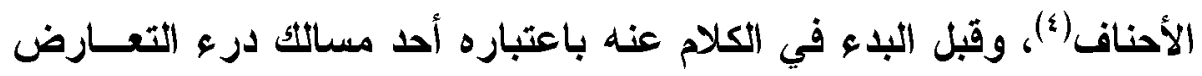
نقف على تعريفه ومفهومـه. فالنسخخ لفهة: يطلق على الإزالة، يُقال: نسخت الثمس الظل؛ إذا أزالته وخلفته وعلى النقل والتحويل، يقال: نسخت ما في الخلية من العسل والنحل إلى أخرى. ومنه نسخ الكتاب، والمناسخات في المواريث، وهو انتقال المال

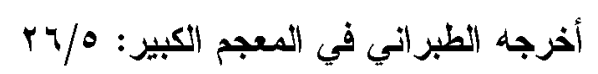

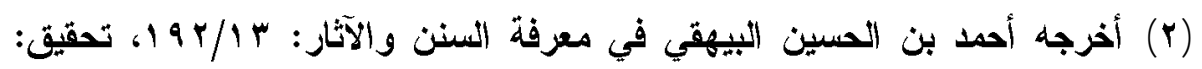

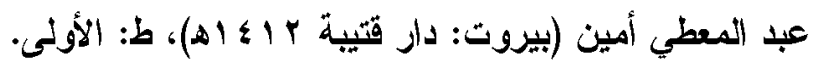

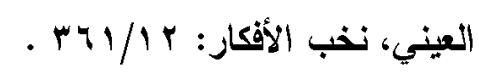

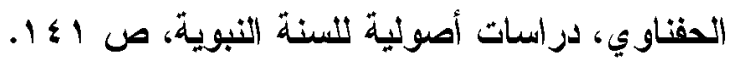


من وارث إلى آخر ولا يتحتم فيه المحو والاتعدام، فــيس نســخ الكتــاب

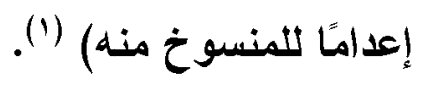

والنسخ اصطلاحًا: (رفع الحكم الثابت بخطاب متقدم بخطاب متر اخ عنه) (r).

وقال الثوكاني: (هو رفع حكم شرعي بمثله مع تراخيه عند) (rاب.

وقد بيّن الحافظ العيني شروط الحديث التاستخ في كتابه نخب الأفكـار؛

فقال في الجمع بين حديثين ما نصه: (ولا نسلم أن من شرط التاستخ ذلــــ،

بل يكفي فيه أن يكون صحيحًا متأخرًا معارضًا غير ممكن الجمع بينه وبين

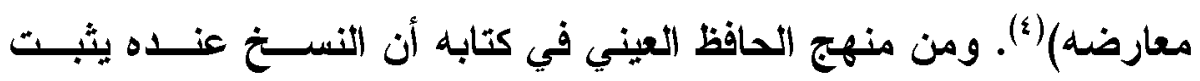

بأمور منها:

ا- قول الصـحابي، ومثثال ذلك قولهله معلقًا على حديث: "توضــؤوا ممـــا

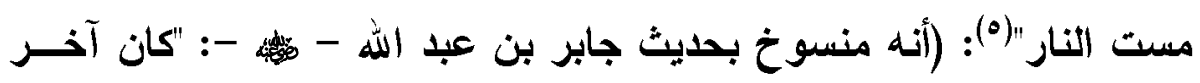

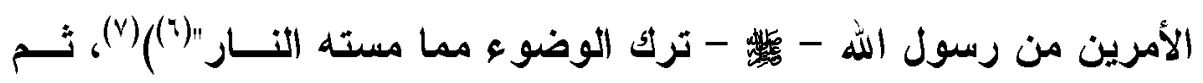

(1) السخاوي، فتح المغيث: ؟V/؛؛، معجم مقاييس اللغة، أحمد بن فارس القزويني:

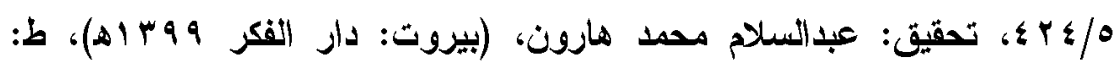

الأولى.

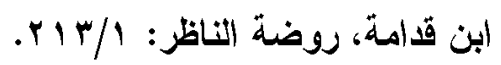

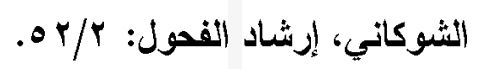

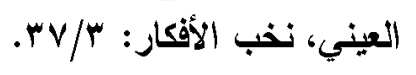

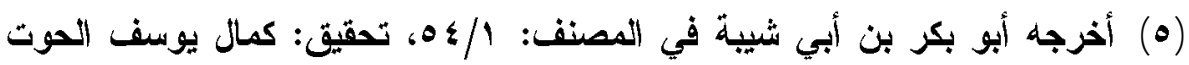

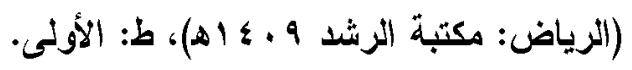

$$
\begin{aligned}
& \text { أخرجه أبو داود في السنن: } 91 / 1
\end{aligned}
$$

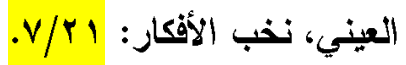

\subsection{9}

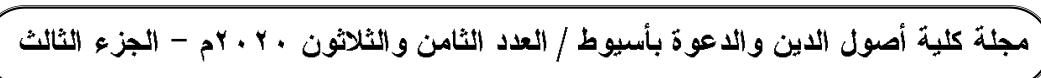




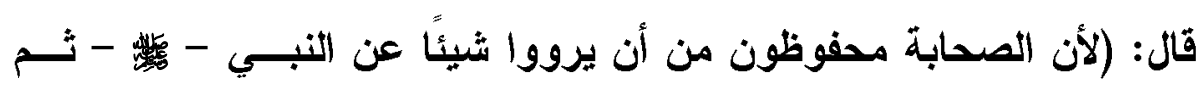
يقولون أو يفعلون بخلافه إلَّا بعد ثبوت النستخ عندهم)(").

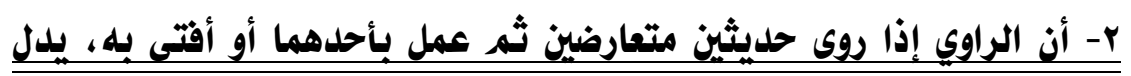

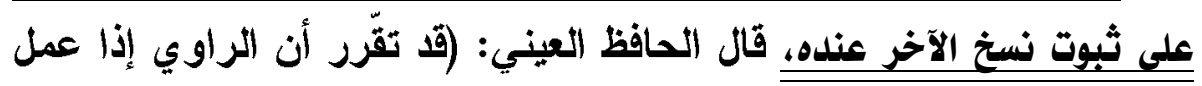
بخلاف ما روى، أن ذلك فيه احتمالات كثيرة، وأحسنها أن يحمل مــا رواه على النستخ، تحسينًا بالظن في حق الصحابي) (ان. ومثاله عندما شرح مسألة ذكر الله بدون وضوء وذكر حديث نافع قال:

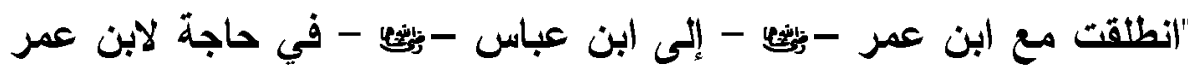

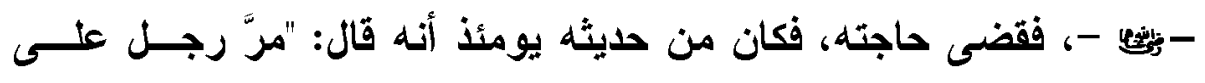

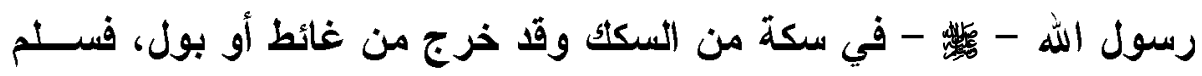

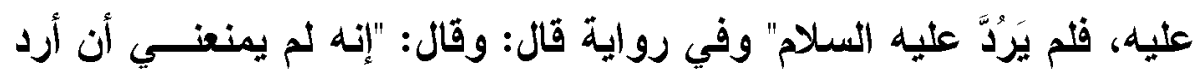

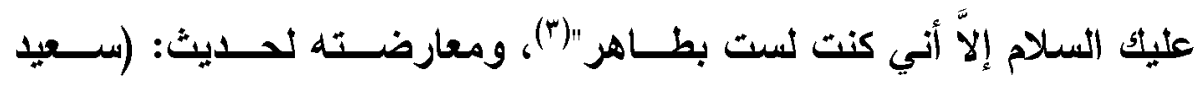

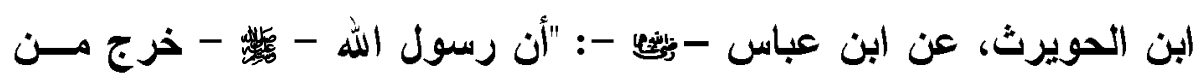

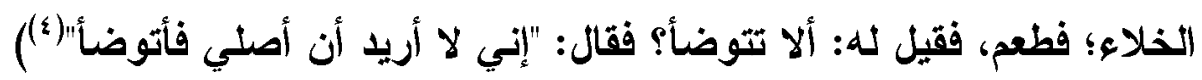
فأخبر أن الوضوء إنما يُراد للصدلاة لا للأكر.

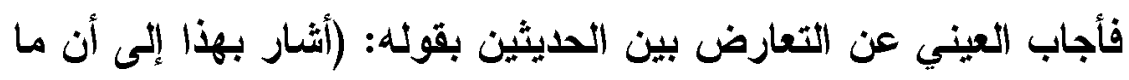

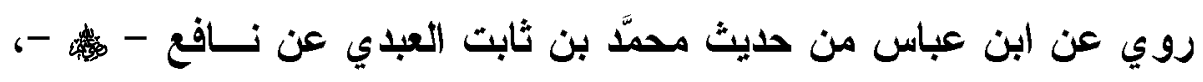

$$
\begin{aligned}
& \text { (1) العيني، نخب الأفكار: 1/r ه. }
\end{aligned}
$$

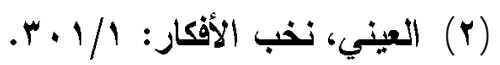

$$
\begin{aligned}
& \text { ( أخرجه أبو داود في السنن: }
\end{aligned}
$$

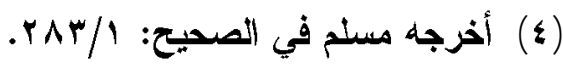




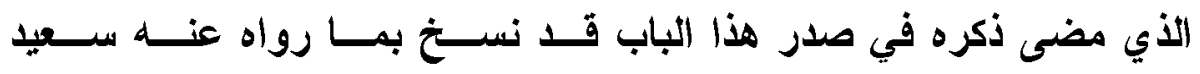

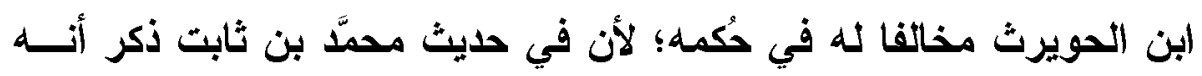
السلام إلاًّ أني كنت لست بطاهر"، وفي حديث سعيد بن الحويرث لما قيل له:

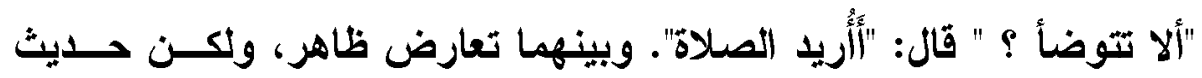
محمَّ بن ثابت منسوخ، والاليل عليه أن ابن عباس عمل بحــيث ســعيد

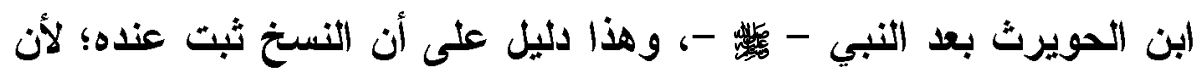
الراوي إذا روى حديثين متعارضين ثم عمل بأحدهما أو أفتى به، يدل على بلى ثبوت نسخ الآخر عنده) ('). وقال في موضع آخر: (وقد ذكرنا عن قريــب أن الــراوي إذا عمـلـ بخلاف ما روى أو أفتى بخلافه دل ذلك على انتساخ الحكم الأول عنده وإلا

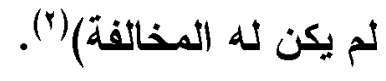

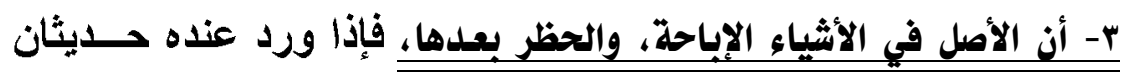
أحدهما يُبيح حكما والآخر يحرمه؛ فغالباً يُرجح التحريم؛ ويحكم على الآخر

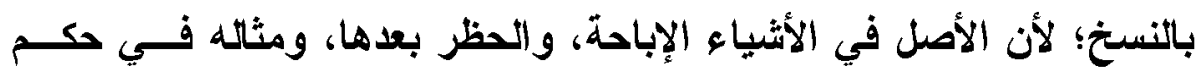

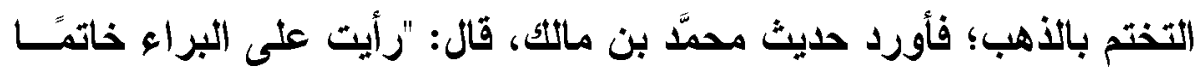

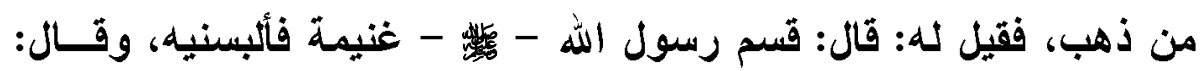
البس ما كساك الله ورسوله"(") وعلق على الحديث بقوله: (إسناده حسـن

$$
\begin{aligned}
& \text { (1) العيني، نخب الأفكار: rrv/r }
\end{aligned}
$$

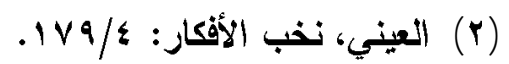

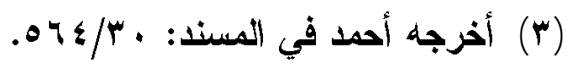


جيا، ورجاله ثقات)("). ثم حكم عليه بأن الحديث منسوخ مـ صحته لورود

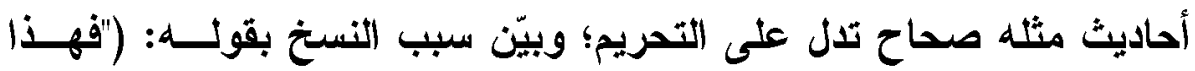

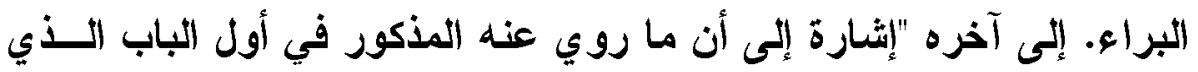
احتج بـه من يذهب إلى إباحة خاتم الأهب منسوخ؛ لأن الأصل في الأثتــياء

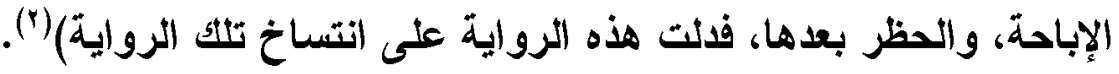
ع- النسخ بالإجماع: جمهور الأصوليين عثى أن الإجماع لا يجوز أن يكون

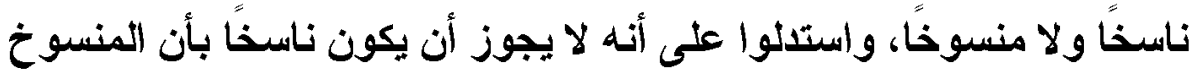

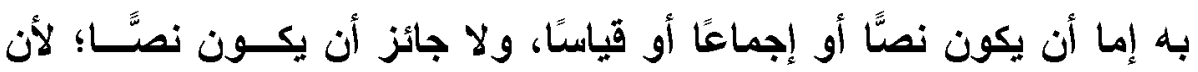

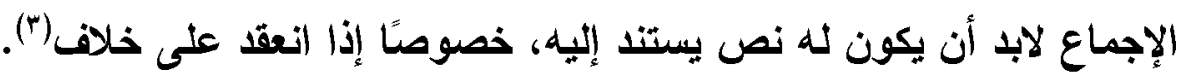

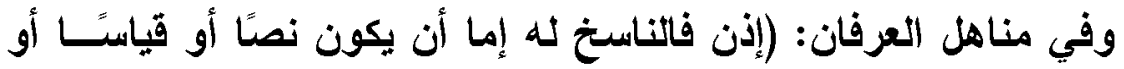

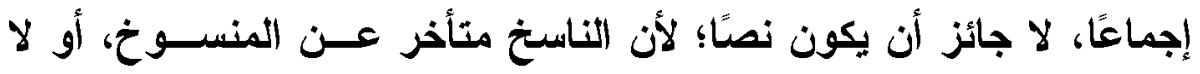

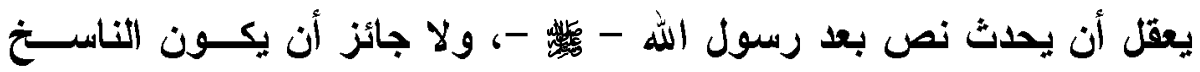
للإجماع قياستًا؛ لأن نسخ الإجماع بالقياس يقتضي أن يكون الحكــم الــــال

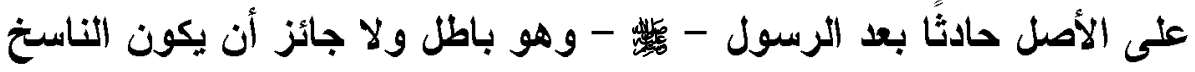
للإجماع إجماعًا لما سبق، وأما قولهم هذا الحكم منسوخ إجماعًا فمعناه أن الإجماع انعقد على أنه نسخ بدليل من الكتاب أو السنة لا أن الإجماع هــو لهو

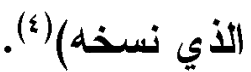

$$
\begin{aligned}
& \text { العيني، نخب الأفكار: r } \\
& \text { rالعيني، نخب الأفكار: r/ }
\end{aligned}
$$

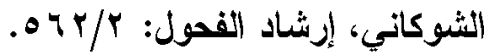

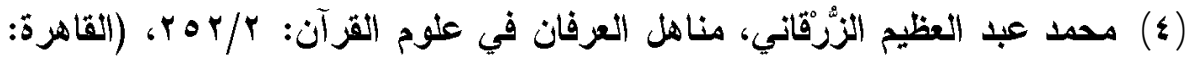

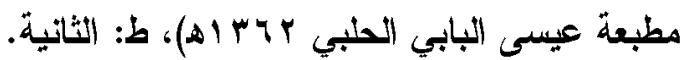


وخالف الحافظ بلر العيني جمهور العلماء خلال عرضه مسـألة عــدد التكبيرات في صلاة الجنازة؛ وجمعه للأحاديث المتعارضة في حكمها بقوله: (فأن قيل: كيف يثبت النسخ بالإجماع ؛ لأن الإجماع لا يكون إلا بعد النبـي -

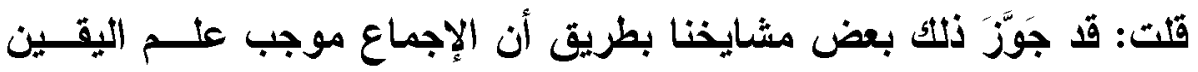

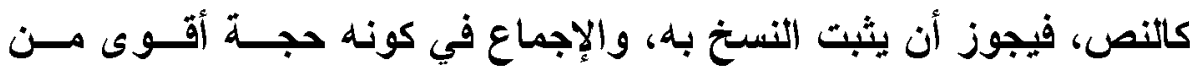
الخبر المشهور، فإذا كان يجوز النستخ بالخبر المشهور، فجوازه بالإجمــاع أولى على أن ذلثك الإجماع بينهم إنما كان على ما استقر عليه آخــر أمسـر

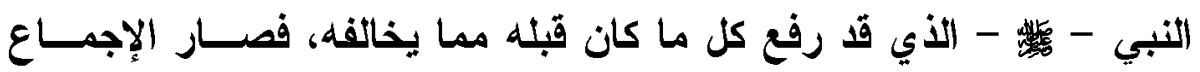

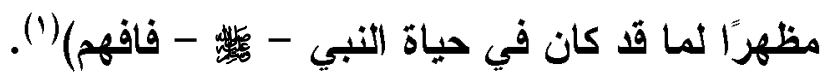
الطريقة الثالثة: التزجيج بين الأحاديث المتعارضة: الترجيح بين الأحاديث المتعارضة هو: تقوية أو تقديم أحســـ الــليلين على معارضه في الظاهر لقرينة من قرائن الترجيح("). ومن قرائن الترجيع عند الحافظ العيني في كتابه نخب الأفكار ما يلي: القرينة الأولى: الترجيح بصحة الحليث إجمالًا: يُثترط في التعارض بين الاليلين أن يكونا في قـوة واحــدة..... ولا تعارض بين حديث صحيح مع حــيث ضــيف أو مسـردود؛ لأن الحـــيث

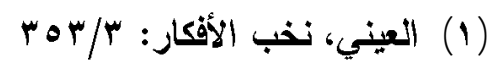

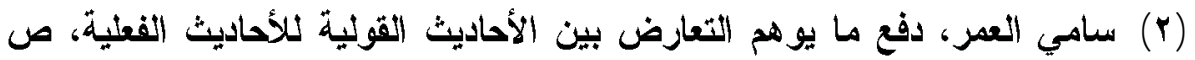

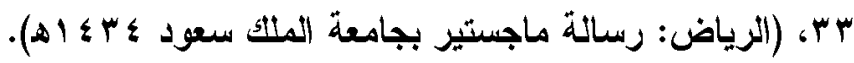


الضعيف أو المردود ليس حجة أصلًا ولا دليّاً(')، ولذا يقول الحافظ العيني: (فاذاذا تعارض الحديثان بُنظر فيهما ليعمل بأصحهما)("). ومثالكه في مسألة: الرجل يحرم وعليه قميص كيف ينبغي أن يخلعه ؟

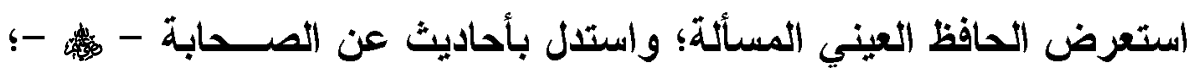

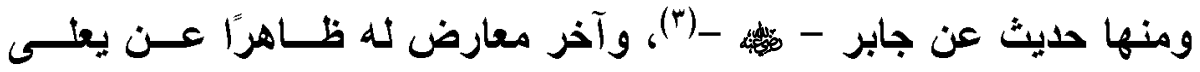

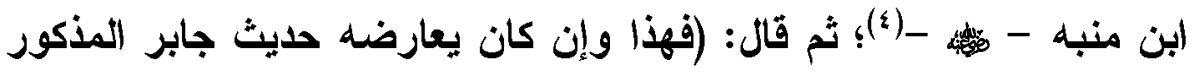
ظاهرًا، ولكن لا يُعتبر بتثك المعارضة لأن من شرطها مساواة الحديثين في

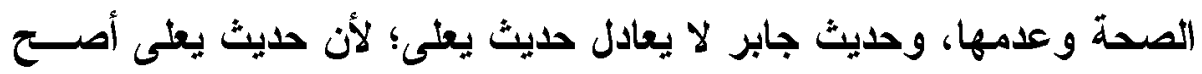

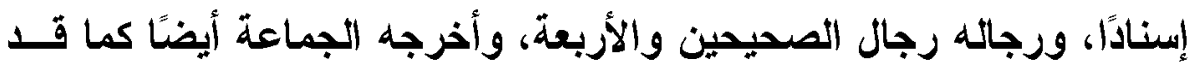
بينا في باب التطيب عند الإحرام، وحديث جابر في سنده عبد الرحمن بـن

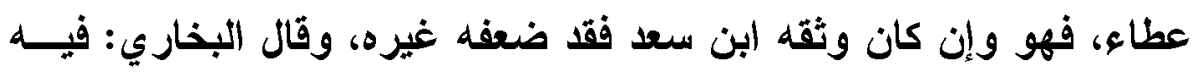

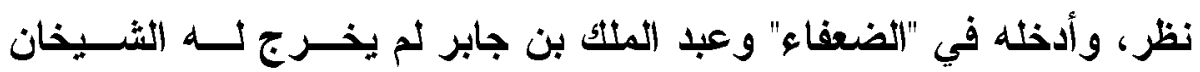
شيئًا، والحديث ذكره عبد الحق الإثبيلي في "أحكامه"، وقال: "عبد الرحمن فئ فئ

$$
\begin{aligned}
& \text { الزحيلي، الوجيز في أصول الفقه: ب/ م ـ ــ. }
\end{aligned}
$$

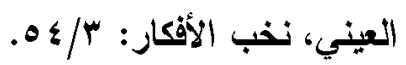

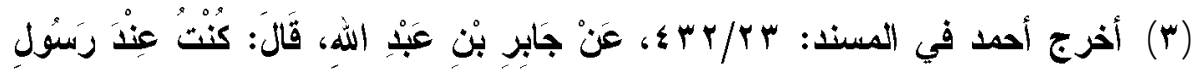

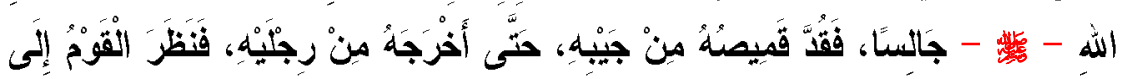

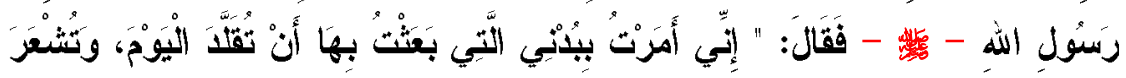

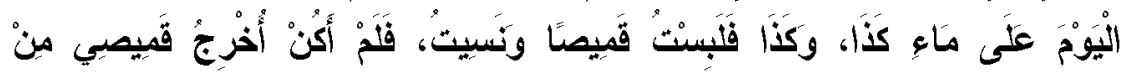

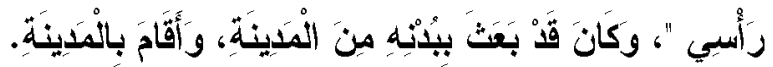

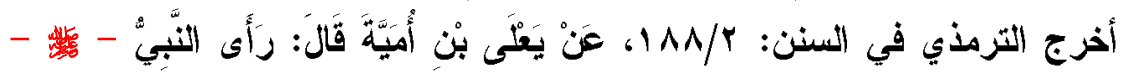

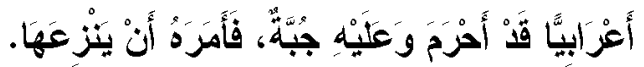


(بن عطاء ضعيف")(")

\section{القرينة الثانية: الترجيح بموافقة القرآن لأحل الدليلين:}

يقول الباجي: (أن يكون أحد الحديثين يوافق ظـاهر الكتــاب والآخــر

يخالفه، فيكون الموافق لظاهر الكتاب أولى)(").

ومثالثه قول العيني عند إيراده لروايات أحاديث صلاة الخوف: (فهـــان

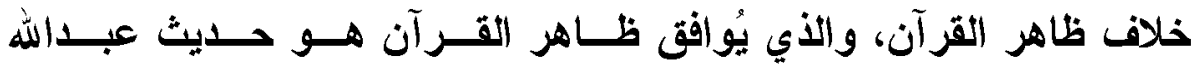

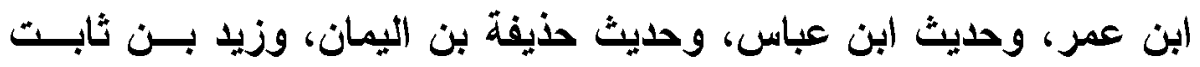
أبي عياش الزرقي، وجابر بن عبدالله - الئتب -)(r).

القرينة الثالثة: الترجيح بتقديه الروايات المثبتة على الروايات النافية:

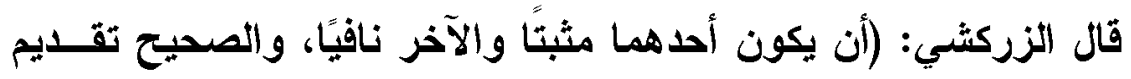

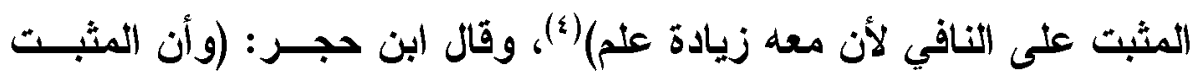
مقدم على النافي وهو وفاق من أهل العلم إلا من شذا)(ه).

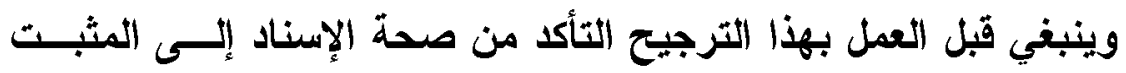

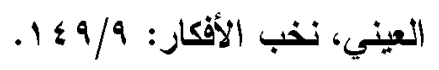

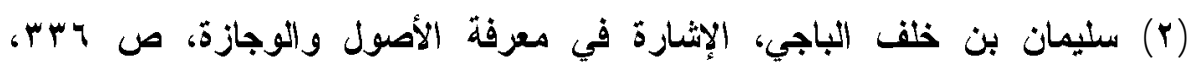

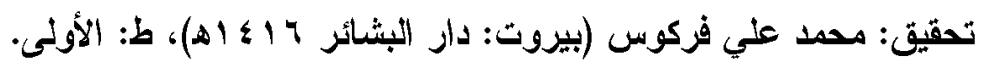

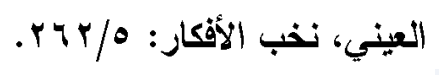

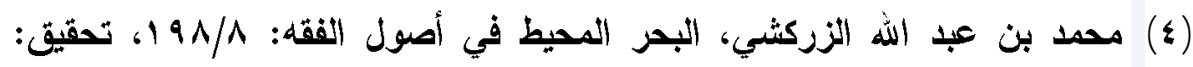

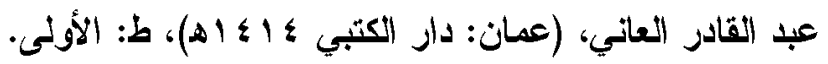

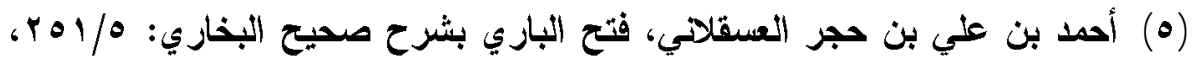

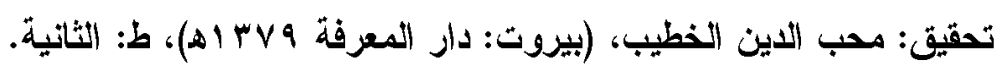


والتأكد من أن المنفي هو نفس المثبت لا غيره أو أخص منه أو أعم فكثيرًا ما ينصب التعارض بينهما ويكون المنفي غير المثبت؛ قال ابن فورث: (وإن كان النافي أخص من المثبت فالحكم للأخص)("). ومثالثه قول العيني عند إيراده الروايات المتعارضة ظاهرًا فـي صسلاة

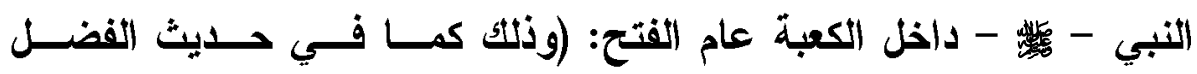

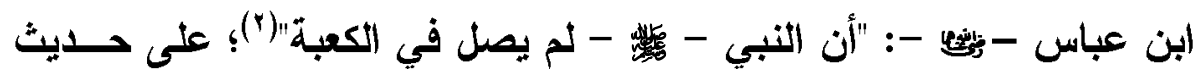

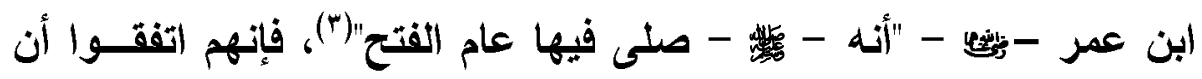

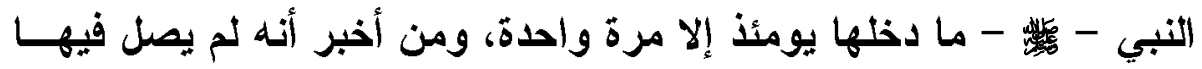

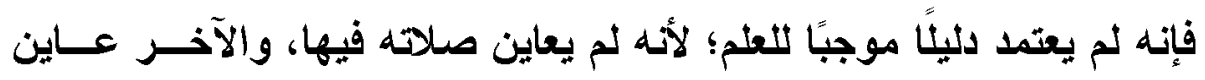

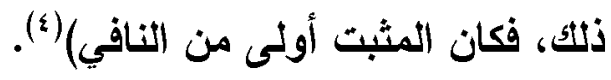
القرينة الرابعة: الترجيح بكثرة الرواة للحليث من الصحابة:

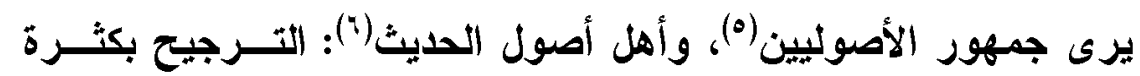

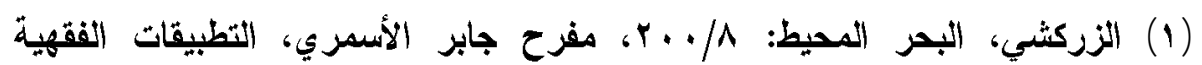

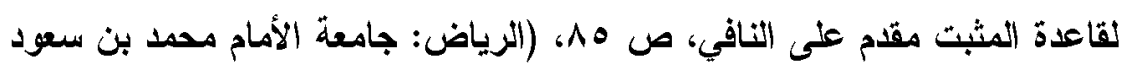

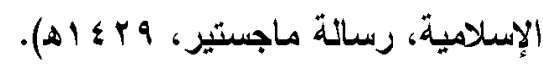

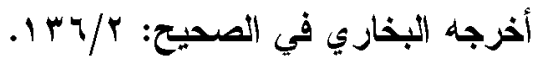

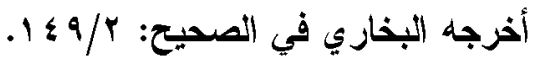

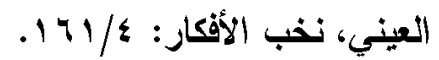

محدد بن عبدالله بن العربي، المحصول في علم أصول الفقه، ص 9 هـالا، تحقيق:

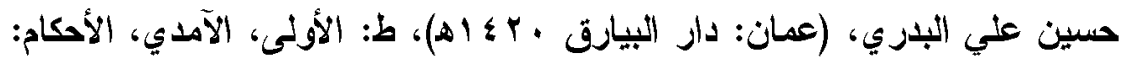
.$\leqslant 4 \% / \varepsilon$

عبدالرحيم بن الحسين العراقي، التقييا والإيضاح شرح مقدمة ابن الصلاح، = 
الرواة إذا تعارض خبران صحيحان، ولم يبلغ درجــة التـواتر، ويسـتوي

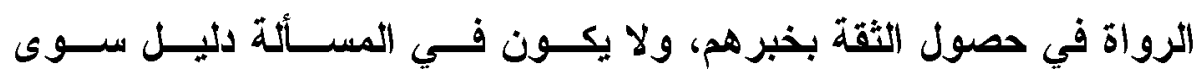
الخبرين (') أزين

وذهب العيني مثلهم إلى الترجيع بكثرة الرواة فقال: (إن الاعتماد عثى كثرة الرواة إنما يكون بعد صحة الاليلين)(r)، وقال في موضع آخر: (وكثرة

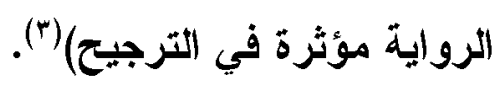

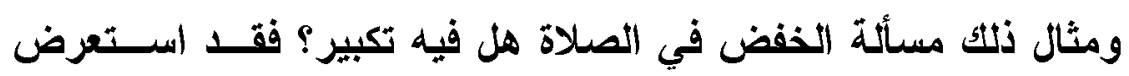
الحافظ العيني الآثار الواردة عن عبد الله ابن مسعود، وأبي مسعود البدري،

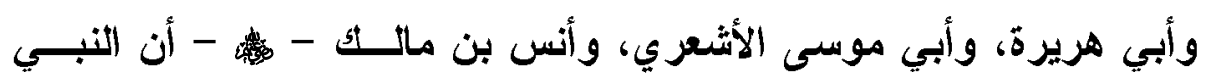
-

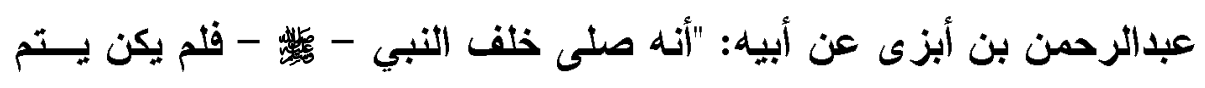

= ص rVY، rV تحقيق: عبدالرحمن محد عثمان، (المدينة المنوزة: المكتبة السلفية

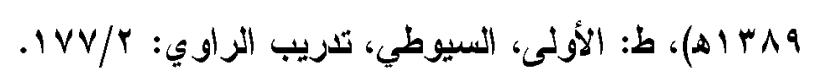

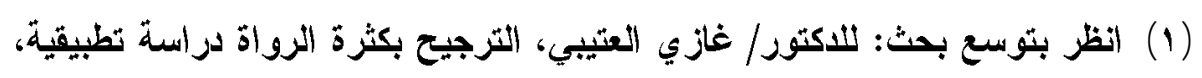

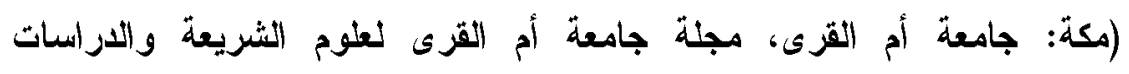

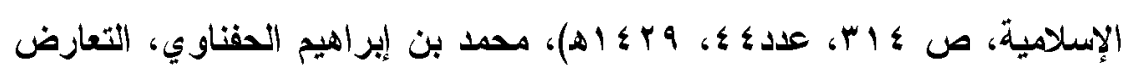

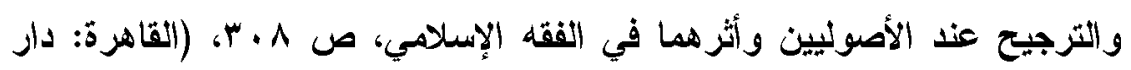

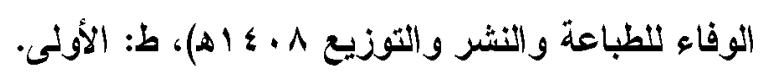

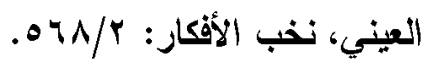

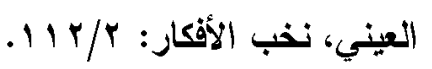

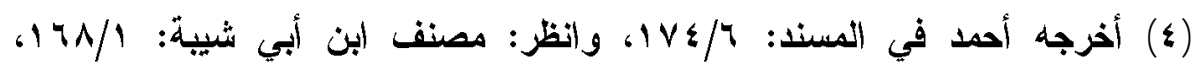
و المعجم الأوسط للطبر اني: 11/1 اجمئ 
التكبيز، وكان لا يكبر إذا خفض""(1) فقال: (وقا عرف أن من جملة أسـباب الترجيح كثرة عدد الرواة وشهرة المروي، حتى إذا كان أحد الخبرين يرويه

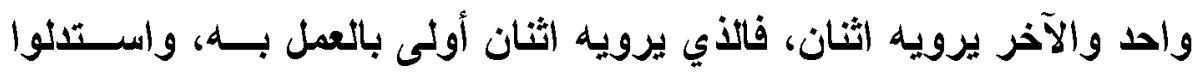
على ذلك بمسألة كتاب الاستحسان في الخبر بطهارة الماءء ونجاسته، وحل الطعام وحرمته، أنه إذا كان المخبر بأحد الأمرين اثنين وبالآخر واحدًا، فإنهـ يُؤخذ بخبر الاثتين؛ وهذا لأن خبر المثثى حجة تامة في بــاب الثـــهادات، بخلاف خبز الواحد، فطمأنينة القلب إلى خبر المثنى أكثر، وقد الثتهر عـن

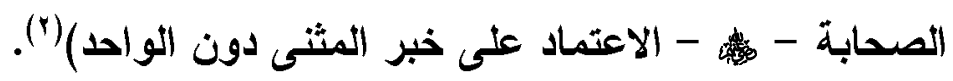
القرينة الخامسة: الترجيح باعتبار اتقان الراوي ضبطًا وحفظًا:

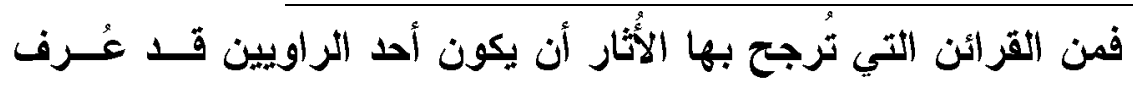

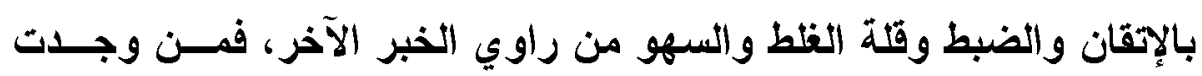
فيه هذه الأوصاف تكون روايته أرجح لأتها أغلب على الظن (r). ومثال ذلت مسألة نكاح المحرم وإيراد الحافظ العيني حديثين ظاهرهما

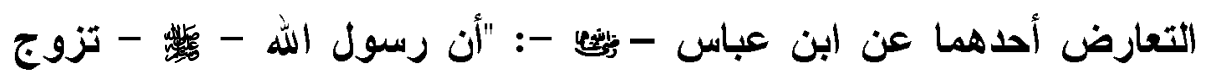
ميمونـة بنت الحارث خالته وهو محرم"(£)، وحديث يزيد بن الأصم: "أن رسول

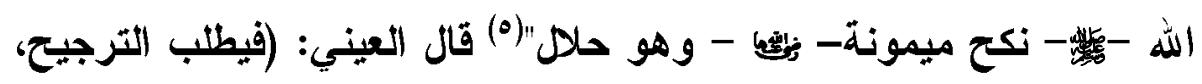

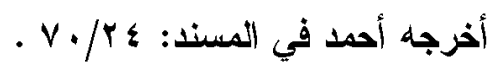

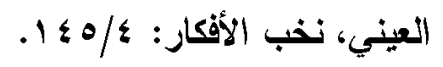

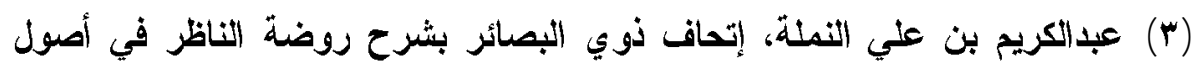

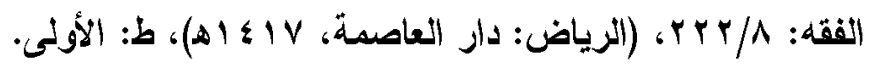

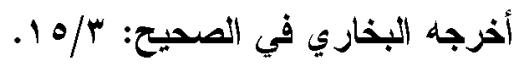

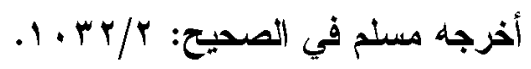


فرجناه بحال الراوي؛ لأنه تعذر الترجيح من نفس الحجة، فأخذنا برواية ابن عباس؛ لأنه روى القصة على وجهها؛ وذلك دليل إتقاته، فكان الأخذ

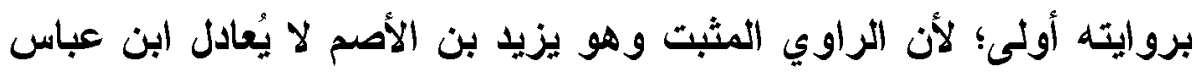

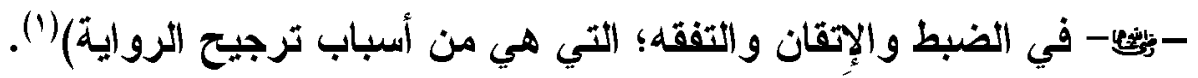

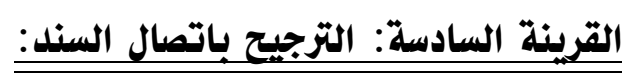
فُيْقَم الحديث المتصل على المنقطع والمرسل لمزيته بالاتصال؛ ومثَّاله

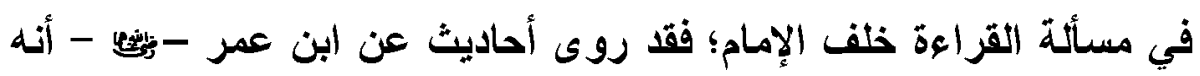

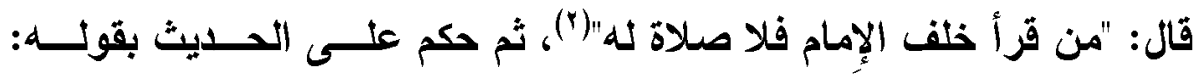
"إسناد صحيح في غاية الصحة".

ثم ذكر رواية أخرى معارضة لهذا الأثر عن ابن عمر أيضًا: يرويهـا

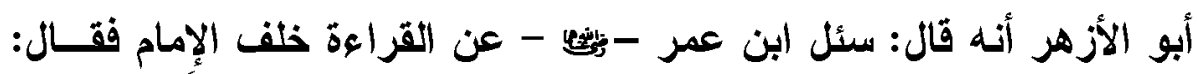
"إني لأستحي من رب هذه البنية أن أصلي صلاة لا أقر أ فيها بأم القر آن" (r).

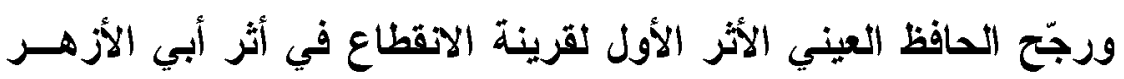

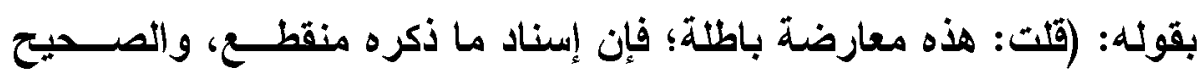

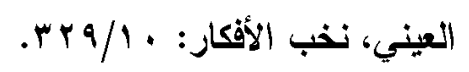

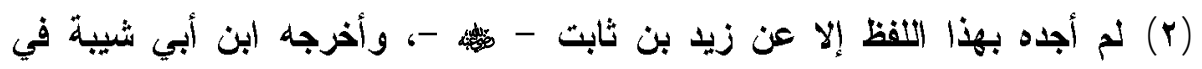

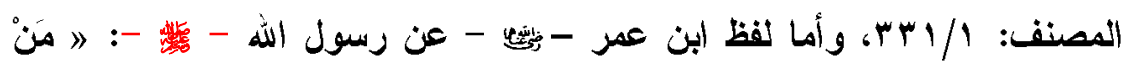

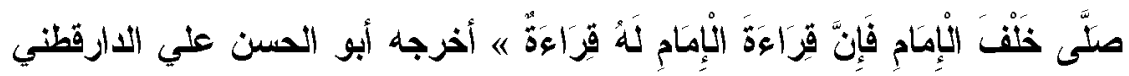

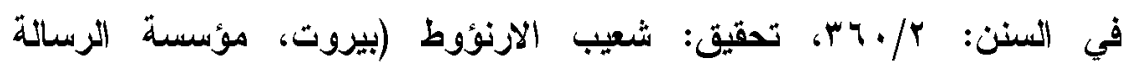

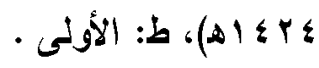

(r) أخرجه عبد الززاق بن همام الصنعاني في المصنف، ص اه اه تحقيق: حبيب

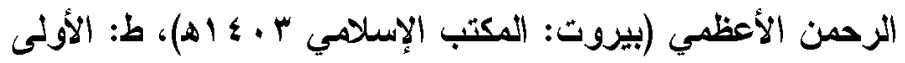


عن ابن عمر - مئهن - عدم وجوب القراعة خلف الإمام)("). القرينة السابعة: ترجيح ما رواه الشيخان على غيرهما:

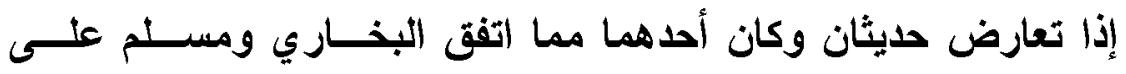
روايته في كتابيهما فإنه يُرجح على ما في كتب غيرهما مــن المحـــثين؛

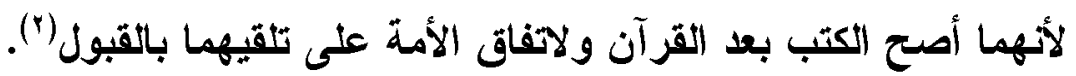

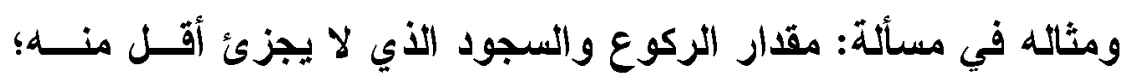

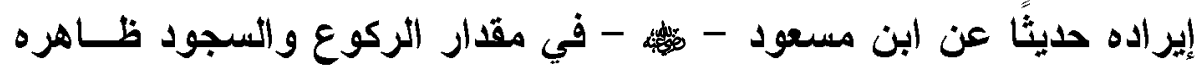
التعارض مع حديثين عن أبي هريزة ورفاعة - مثئه -؛ فقال الحافظ العيني:

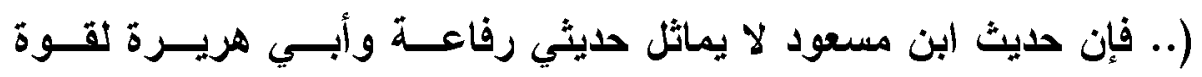

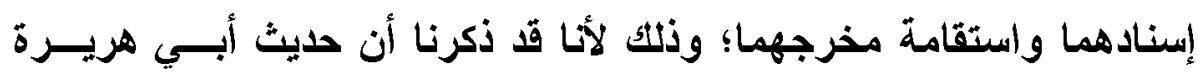
أخرجه الثشيخان وغيرهما، وحديث رفاعة مخرج علـى شــرط البخـاري، وحديث ابن مسعود ليس كذلك، فلا يعارضهما، وتعين الحكم لحديثي رفاعة وني

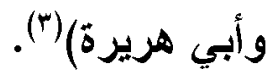

القرينة الثامنة: ترجيج من أخبر عز مشاهدة وعيان على غيره:

إذا كان راوي أحد الحديثين المتعارضين صاحب القصة، أو روى عـن عن عيدة

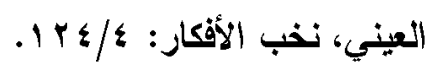

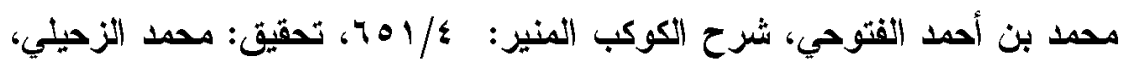

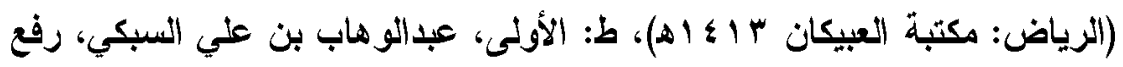

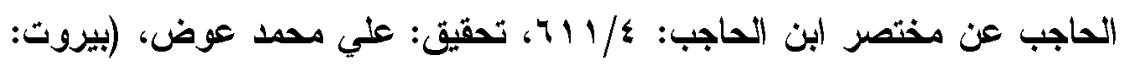

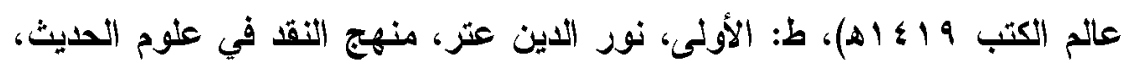

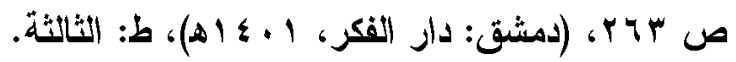

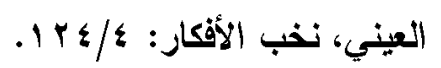


مشاهدة وعاين الخبر المروي، فإن حديثئه مقدم على غيره، وتكون قرينــة لترجيع حديثله على غيره؛ لأنه أعلم بما جاء في الحديث.

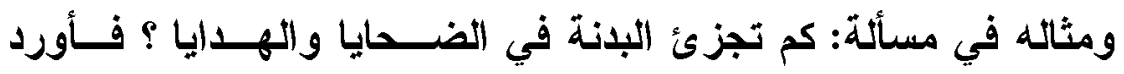

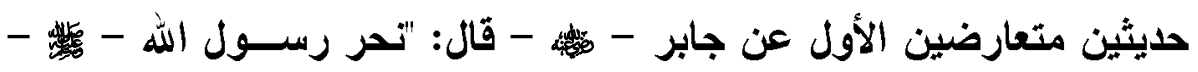

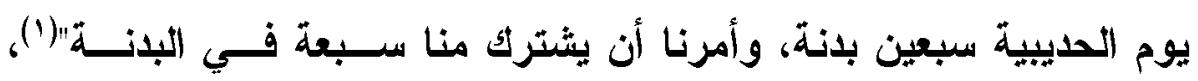
وحديث المسور بن مخرمة ومروان بن الحكم قالا: "خرج رسول الله -

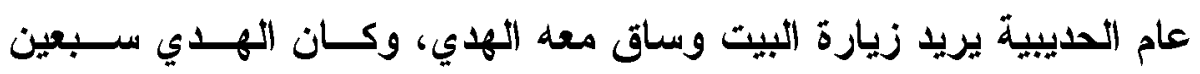

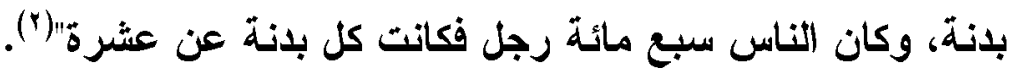
فقال الحافظ العيني: (... وما رواه جابر أولى بالعمل؛ لأنه يُخبر عـن لهن

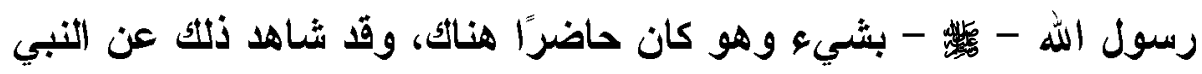
لم يكن معه يوم الحديبية؛ فخبر الأي أخبر عن مثاهدة وعيان أقوى مــن وإن

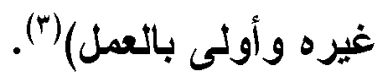
القرينة التاسعة: ترجيج رواية أهل الملدينة:

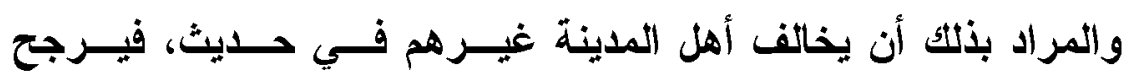

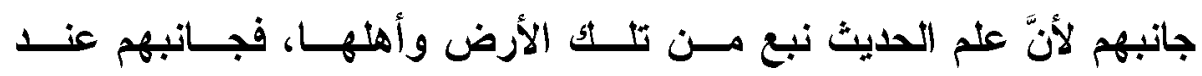

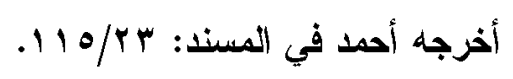

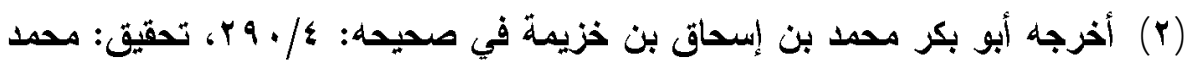

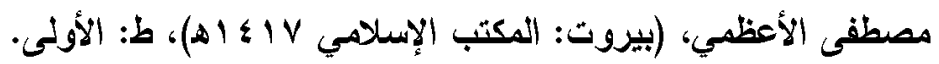

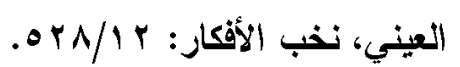




\section{الاختلاف أقوى (')}

ومثاله عند الحافظ العيني: ترجيحه روايات من روى من الصحابة أنه

مذهب أهل المدينة قديمًا وحديثًا ترك الجهر بها، ومنهم من لا يرى قرائها

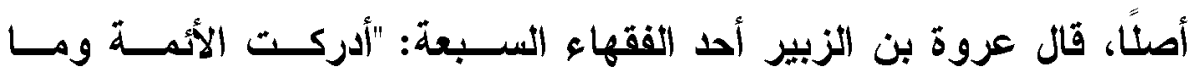

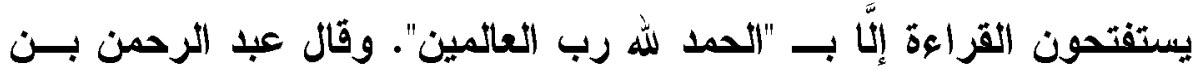

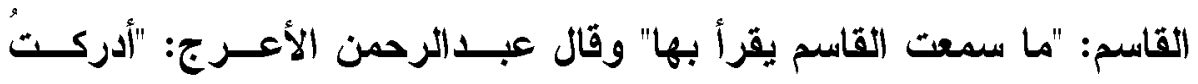

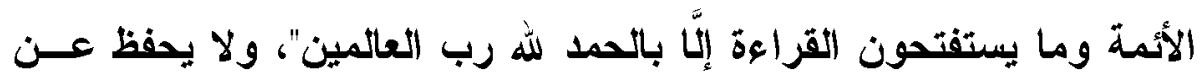
أحد من أهل المدينة بإسناد صحيح أنه كان يجهر بها، إلَّا شيء يسير، وله وله

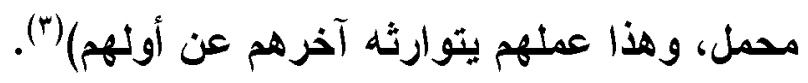
القرينة العاشرة: ترجيح ما سله من الاضطراب:

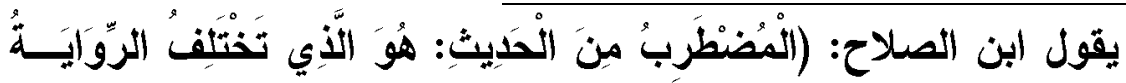

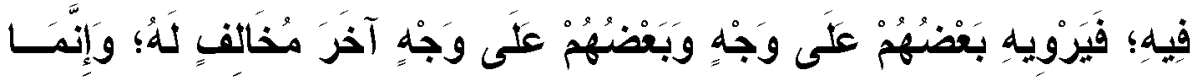

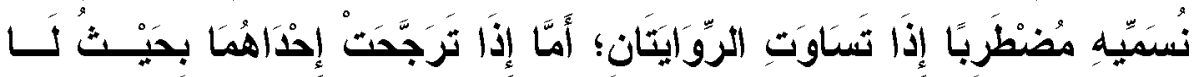

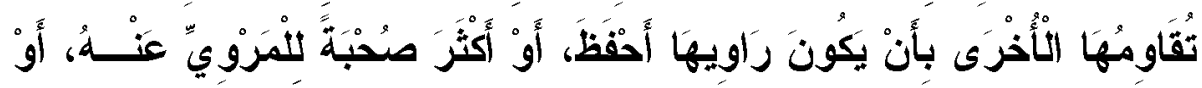

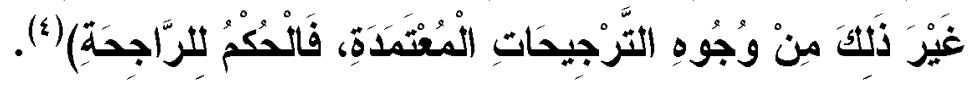

(1) انظر للفائدة ويتثرع: موسى اسماعيل، عمل أهل المدينة وأثره في الفقه

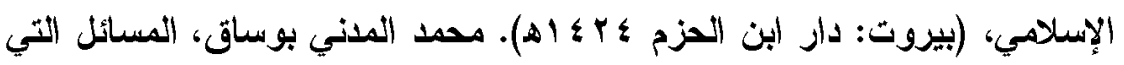

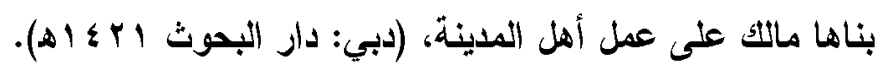

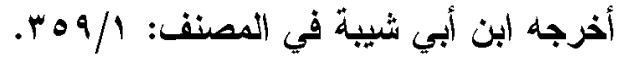

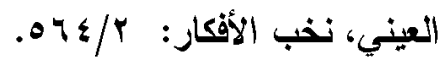

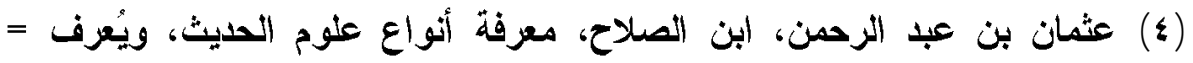


فإذا تعارض حديثان وكان إسناد أحدهما أو متنه سائمًا من الاضطراب، وإنما ذكره الر اوي بلفظ واحد والآخر مضطرب بأن يُروى بســند أو مــتن مضطرب، ولا يوجد مرجح بينهما؛ فإنه يُرجح الحديث الأبي لــــ يضـطرب سنده أو متنه عثى الحديث الأي اضطرب سنده أو متنه|('). ومثالته ما نقله الحافظ العيني من الأحاديث المتواترة عن رســول الله -

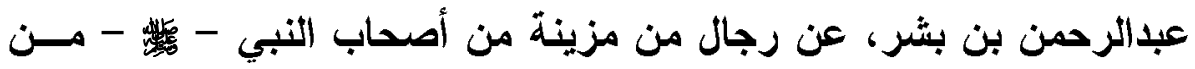

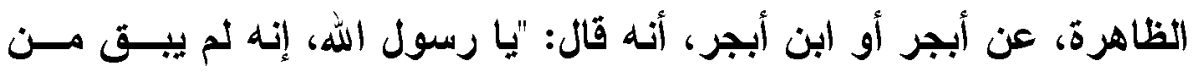

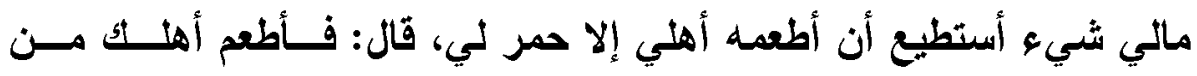

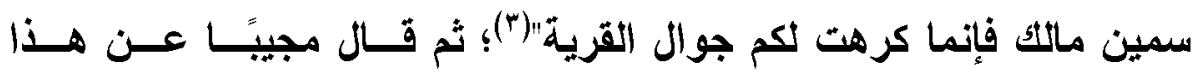
التعارض: (والأحسن في هذا أن يُقال: لا يُعارض حديث غالب بـن أبجـر

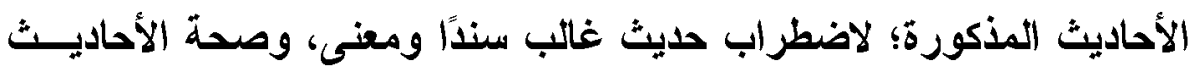

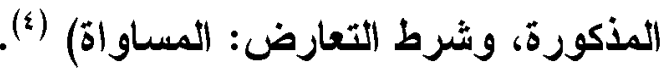

= بمقدمة ابن الصلاح، ص بهو، تحقيق: نور الاين عتر، (بيزوث: دار الفكر

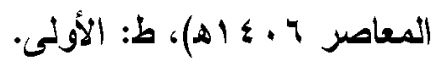

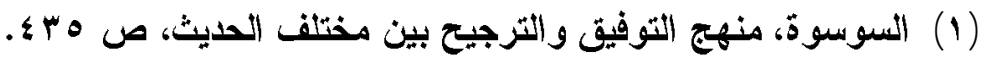

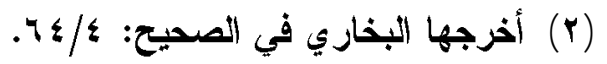

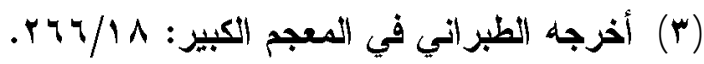

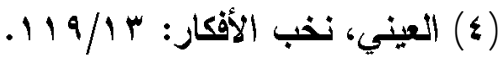




\section{الخاتمة}

الحمد لله الأي بنعمته تتم الصالحات، والصلاة والسلام على رسول الله -

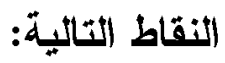

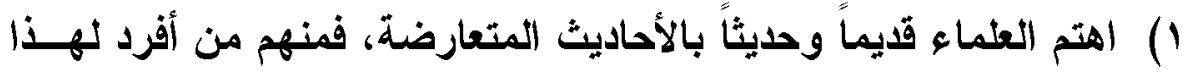

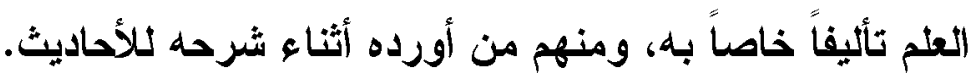

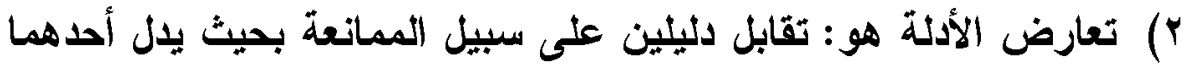
على خلاف ما يال عليه الآخر . المان.

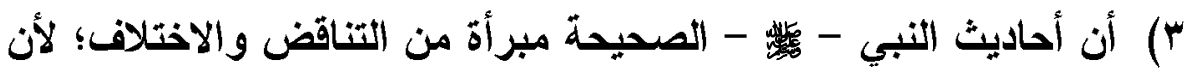

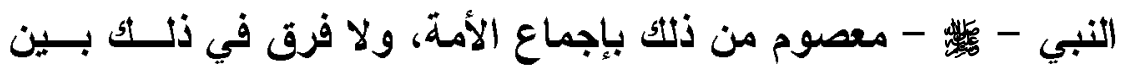

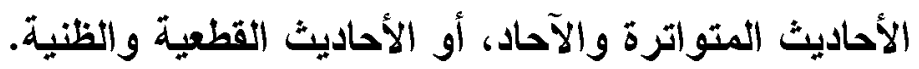

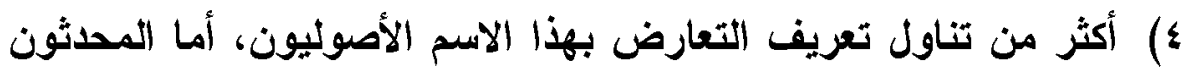
ففالبًا يتناولونها تحت اسم مُختلف الحديث. ه) يجب دفع التعارض بين النصوص الثرعية على الترتيب التالي: الجمع بينها، فإن تعذر فالنسخ، فإن تعذر فالترجيح.

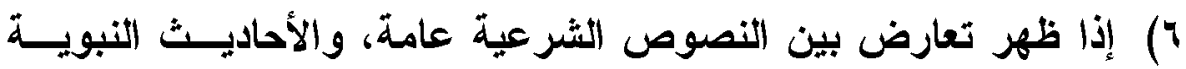

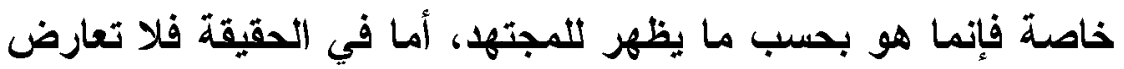
البتة بين الأدلة الثشرعية. V يُتنبر كتاب نخب الأفكار في تنقيح مباني الأخبار في شرح معاني الآثار

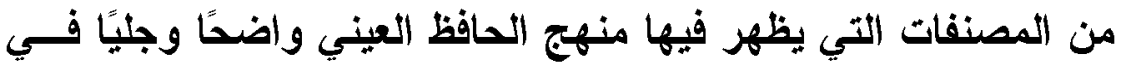
دفع التعارض بين الأدلة؛ لذلك تم الاعتماد عليه في الدراسة. 
^) حرص الحافظ العيني على بذل الجها في التوفيق والجمع بين الأدلــة

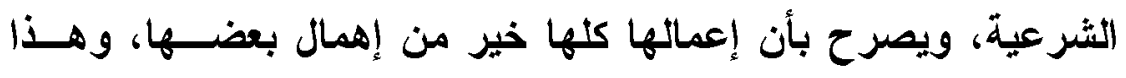

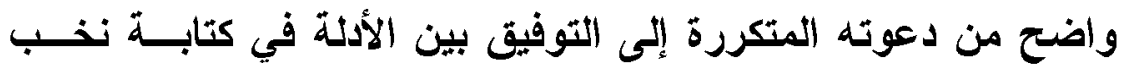
الأفكار، وفي غيرها من مؤلفاته.

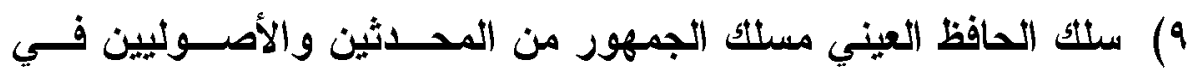

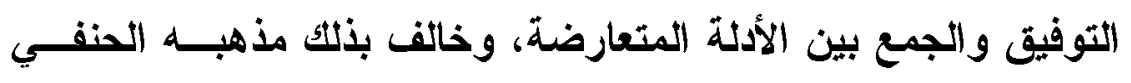

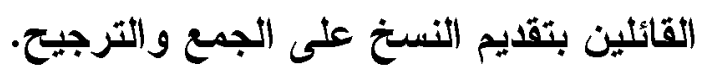

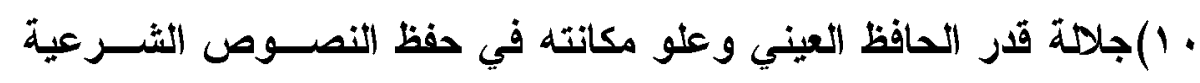

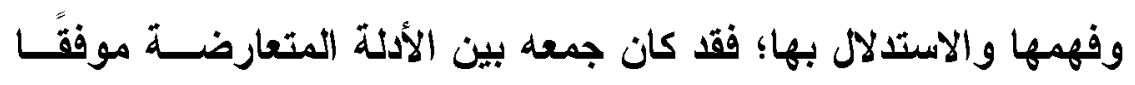
ودقيقًا.

11)

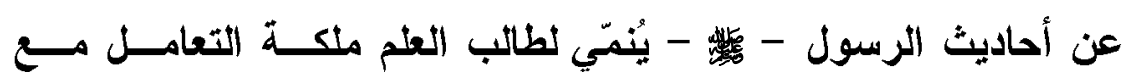

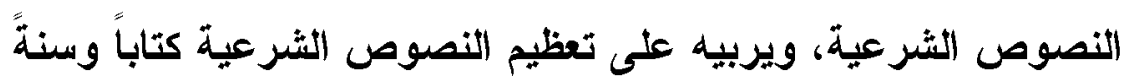
فلا يرد منها شيئاً، بل يجتها في طلب التوفئه علئ والجمع بينها. 


\section{قائمة المصادر والمراجع}

1) ابن أبي شيبة، أبو بكر، المصنف، تحقيـقة: كمـال يوســف الحــوت

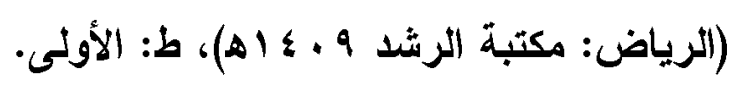

ץ) ابن العربي، المالكي، المحصول في علم أصول الفقه، تحقيق: حسـين

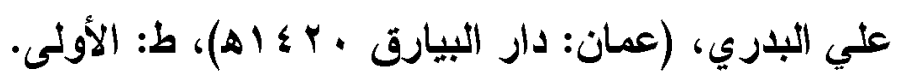

r) ابن تغري، يوسف، النجوم الزاهزة في ملوئ مصر والقاهرة،(القاهرة: وزارة الثقافة المصرية r r آهـ)، ط: الأولى.

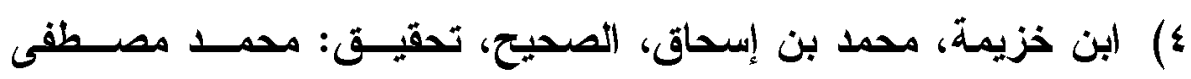

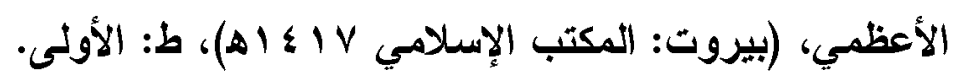

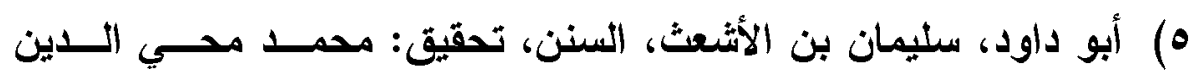

$$
\text { (بيزوت: المكتبة العصرية)، ط: الأولى. }
$$

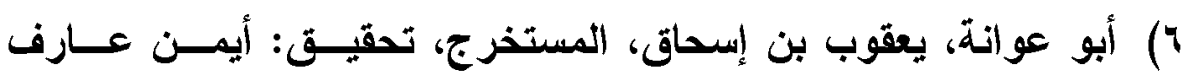

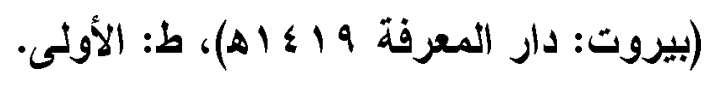

V) إسماعيل، موسى، عمل أهل المدينة وأثره في الفقه الإسلامي، (بيروت:

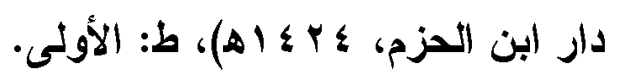

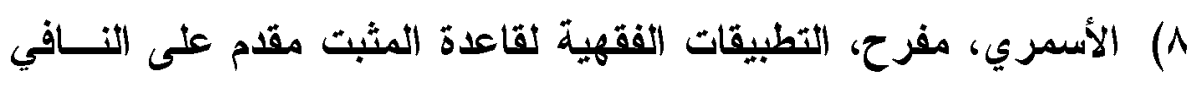
في الجنايات والحدود، رسالة ماجستير، (الرياض: جامعة الأمام محمد

$$
\text { بن سعود (الإسلامية و ج \& 1هـ). }
$$

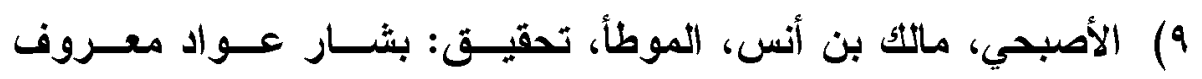

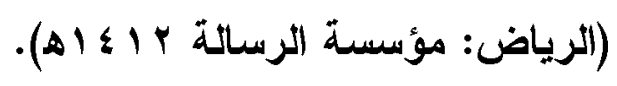

\section{$1 \cdot 14$}

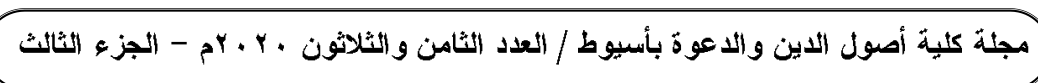


• (1)الآمدي، علي، الإحكام في أصول الأحكام، تحقيق: عبد الرزاق عفيفي، (بيروت: المكتب الإسلامي r + ع اهـ)، ط: الأثانية.

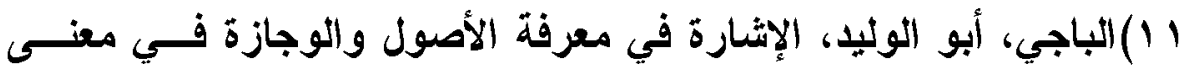

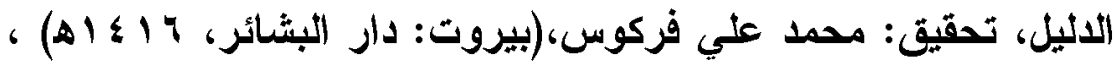

ط: الأولى.

r ا) الباقلاتي، محمد، التقريب والإرشاد، تحقيق: عبد الحميا بـن علــي،

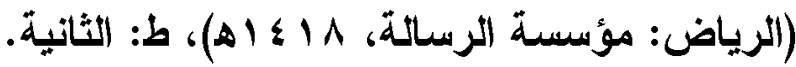

r 1) البخاري، محمد بن إسماعيل، الصحيح، تحقيق: محمد زهيز (القاهرة: دار طوق النجاة r r \& إه)، ط: الأولى.

؛ 1) البزار، أبو بكر بن أحمد، المسند، تحقيق: محفوظ الــرحمن زيــن الله

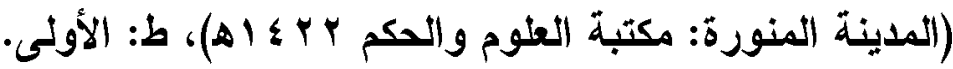
1) البيههي، أحمد بن الحسين، السنن الكبرى، تحقيق: محمد عبد التهـادر

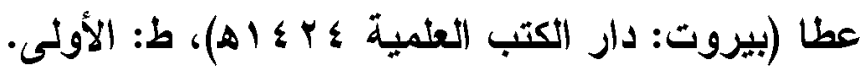
7 1) البيهزي، أحمد بن الحسين، معرفة السنن والآثار، تحقيق: عبد المعطي أمين (بيزوت: دار قتيبة r إع اهـ)، ط: الأولى.

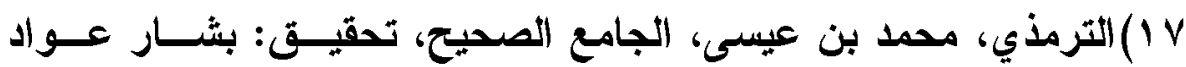

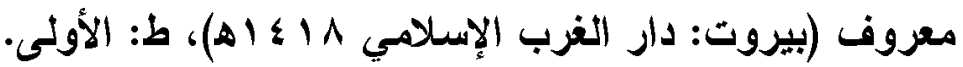

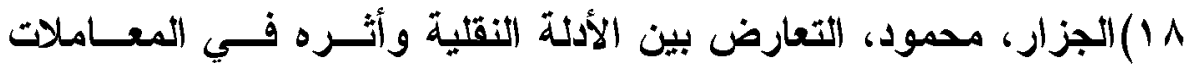

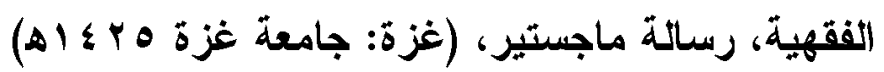

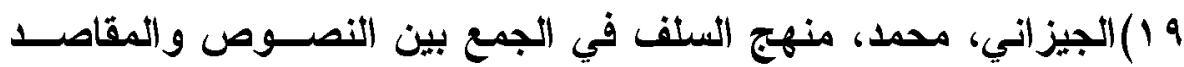

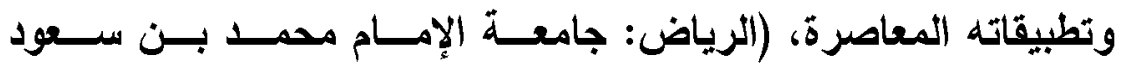

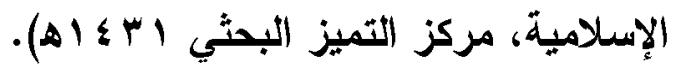




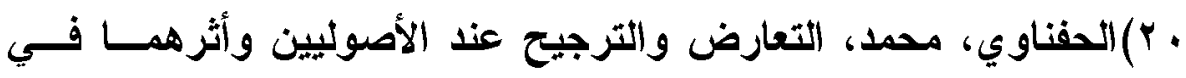

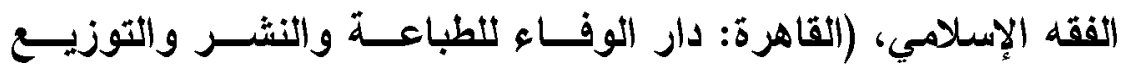

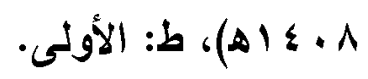

اب)الحفناوي، محمد، دراسات أصولية للسنة النبوية، (القاهرة: دار الوفاء

$$
\text { للطباعة والنثر والتوزيع r أهـ اله)، ط: الأولى. }
$$

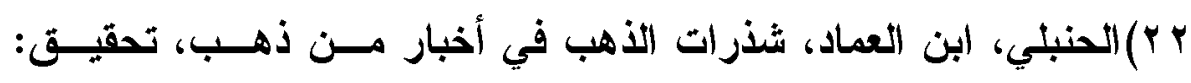
محمود الأرناؤوط، (دمثث: دار ابن كثير ب ا أ اهـ)، ط: الأولى. rY) الزرازي، ابن فارس، مقاييس اللغة، تحقيق: عبد السلام محمد هارون، (بيروت: دار الفكر 99 9 ا اهـ)، ط: الأولى.

ع r)الزحيلي، محمد، الوجيز في أصول الفقه الإسدلامي، (دمشث: دار الخيز

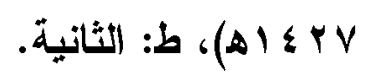

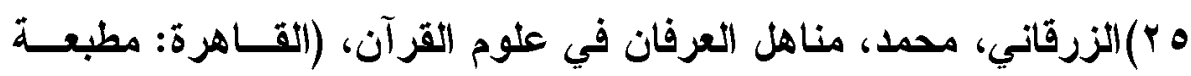

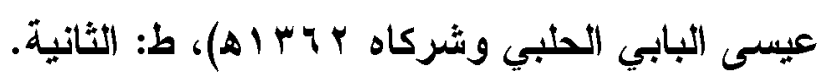
צ Y)(الزركثي، محمد، البحر المحيط في أصول الفقه، تحقيق: عبد القــادر عبد الله العاني، (عمان: دار الكتبي \& أهـ اله)، ط: الأولى.

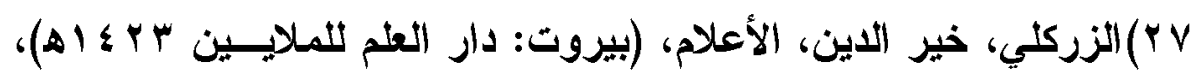
ط: الخامسة عثر. ^ץ)(السبكي، عبد الوهاب، رفع الحاجب عن مختصر ابن الحاجب، تحقيق: علي محمد عوض، (بيزوت: عالم الكتب 19 \&ـ 1ه)، ط: الأولى.

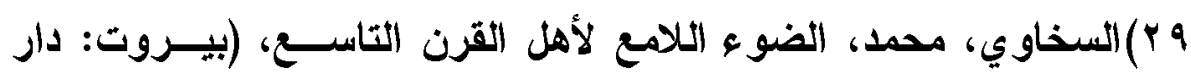

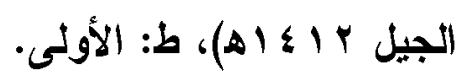




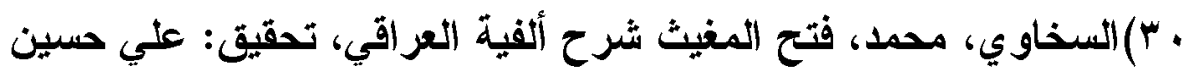

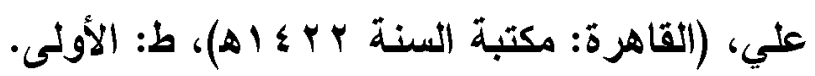

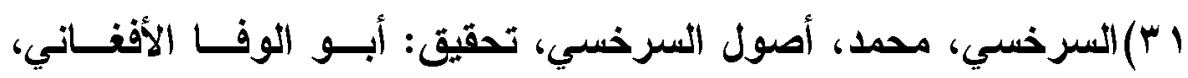

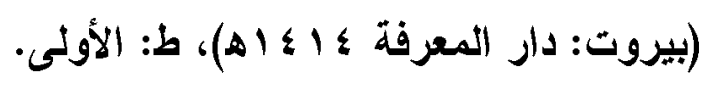

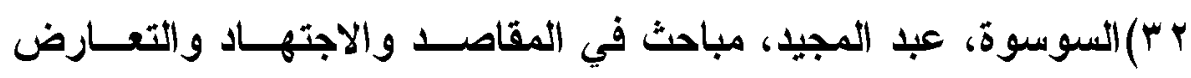

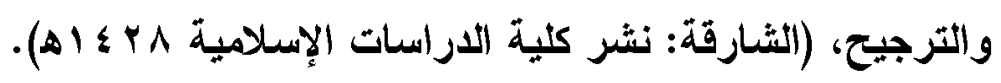

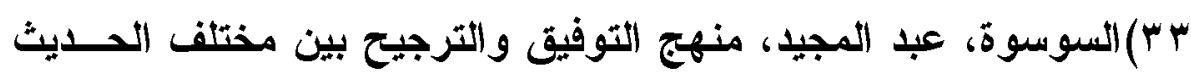

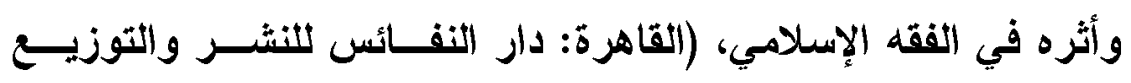

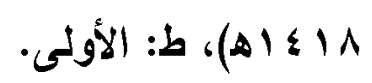

؟ ب)السيوطي، عبد الرحمن، تدريب الراوي شرح تقريب النواوي، تحقيق:

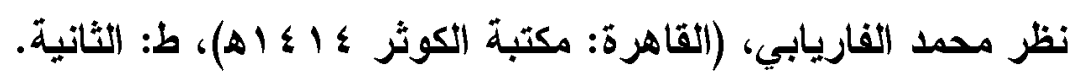

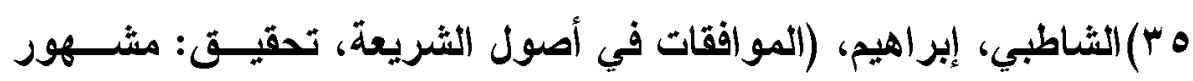

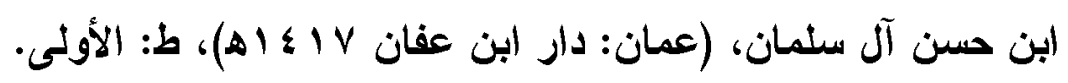

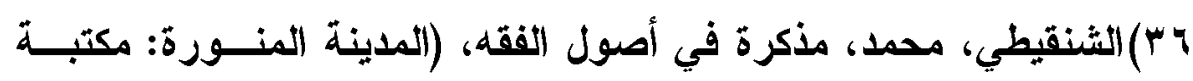

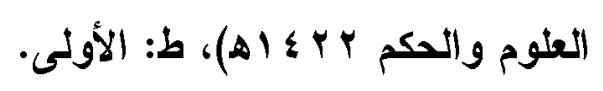

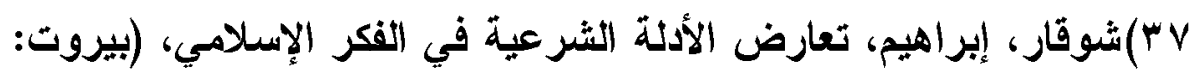

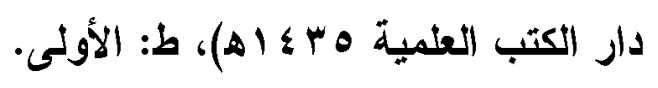

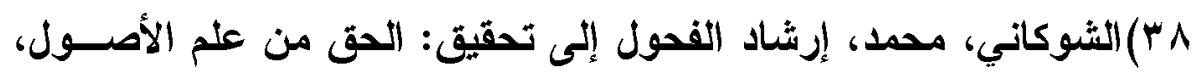

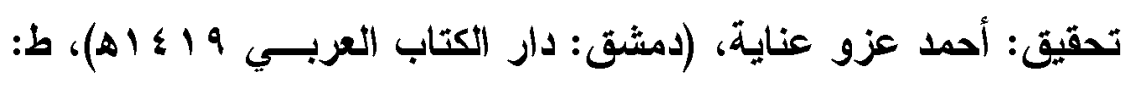

الأولى.

\section{$1 \cdot 17$}

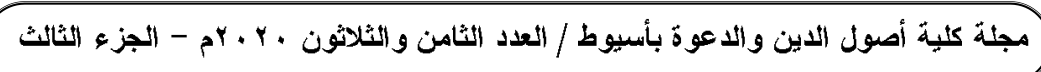


9 r)(الصاعدي، حمد، المطلق والمقيد وأثرهما في اختلاف الفقهاء، (المدينة

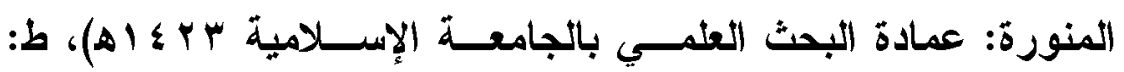

الأولى.

• ـ) الصنعاني، عبد الرزاق بن همام، المصنف، تحقيق: حبيـب الــرحمن الأعظمي، (بيروت: المكتب الإسلامي با + \& اهـ)، ط: الأولى.

اء)|الطبراني، سليمان بن أحمد، المعجم الكبيز، (القاهرة: مكتبة ابن تيمية 10

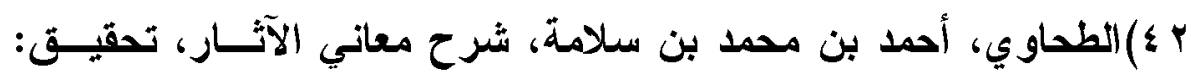
محمد زهري النجار (بيزوت: عالم الكتب \& 1 \& اهـ)، ط: الأولى.

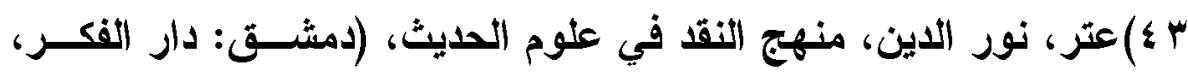

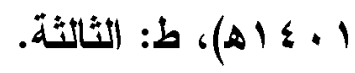

؛ ؛)العتيبي، غازي، الترجيح بكثرة الرواة دراسة تطبيقية،(مكة: جامعة أم

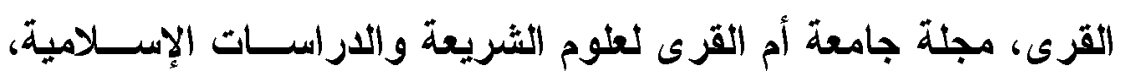
. (ه)

ــ)العثيمين، محمد، الأصول من علم الأصول، تحقيق: مؤسســة الثــيخ

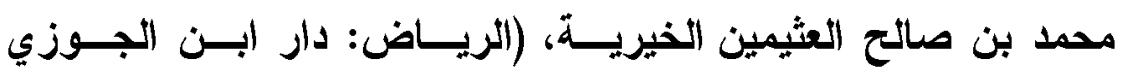
.

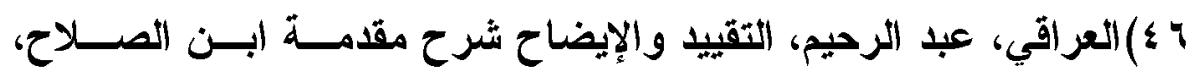
تحقيق: عبدالرحمن محمد عثمان، (المدينة المنورة: المكتبة الســلفية

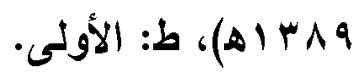

\section{$1 \cdot \lambda v$}

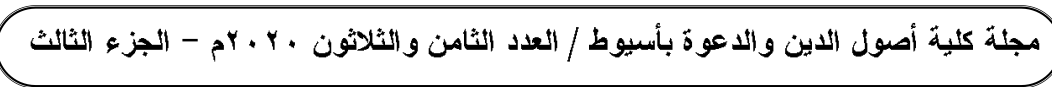


\&V V العسقلاتي، (بن حجر، فتح الباري بشرح صحيح البخـاري، تحقيـق:

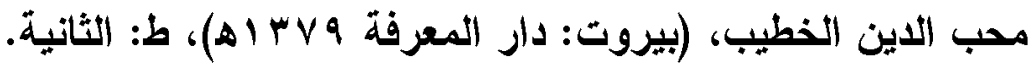

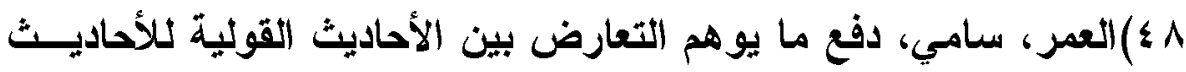

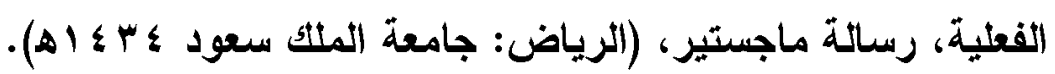

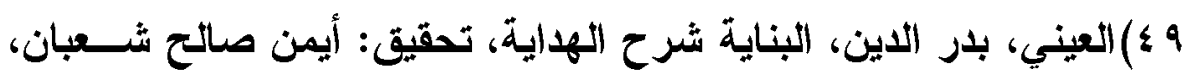

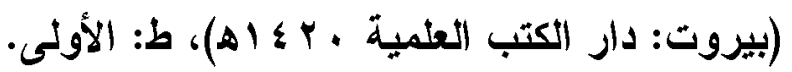

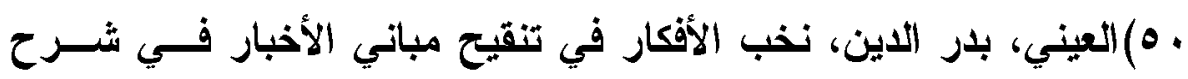

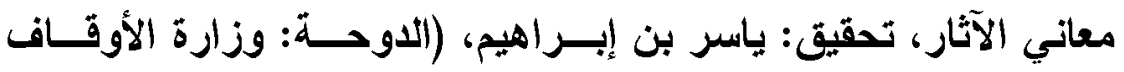

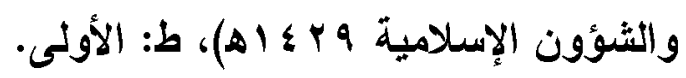

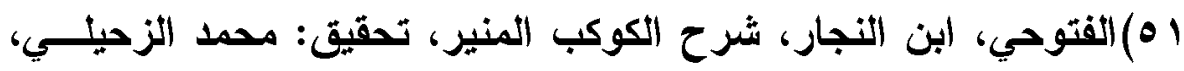

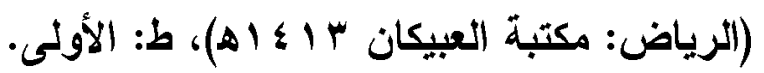
ror)(القثيري، مسلم بن الحجاج، الصحيح، تحقيق: محمد فؤاد عبد الباقي

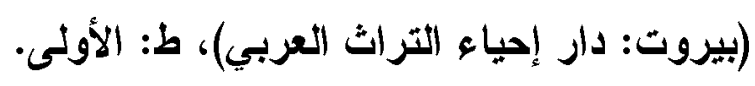

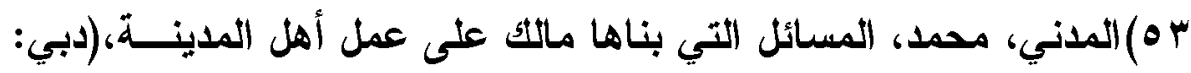

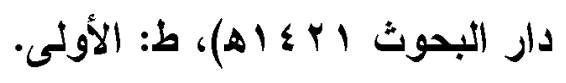

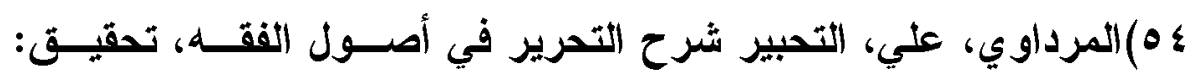

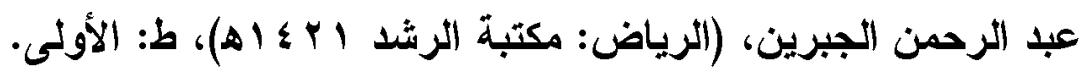
ه م)مقداد، زياد، دلاكة صيغة التهي على الأحكام الثرعية، (تونس: جامعة الثرة

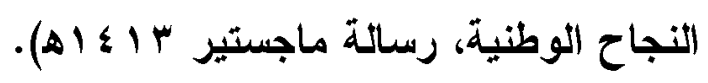

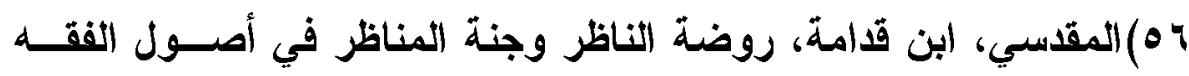
على مذهب الإمام أحمد، (الرياض: مؤسسة الريّان للطباعــة و والنثــر

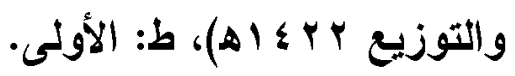




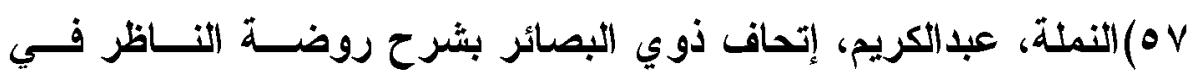

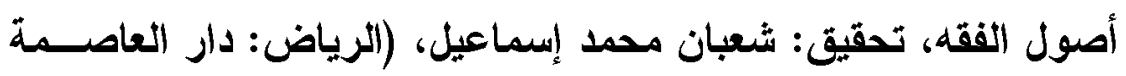

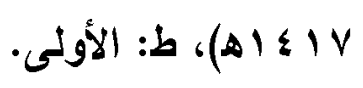

^ه) النملة، عبدالكريم، المهذب في علم أصول الفقله المقارن، (الريــاض:

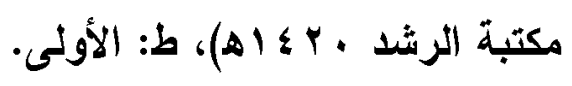

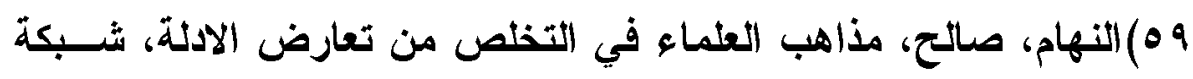
الانترنت، دراسات، مجلة الوعي الإسلامي.

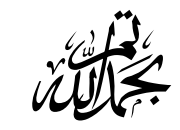

